\title{
Minimumloon, uitkeringsniveau en arbeidsschaarste in de euregio Maas-Rijn
}

Citation for published version (APA):

Meyboom, P. (1992). Minimumloon, uitkeringsniveau en arbeidsschaarste in de euregio Maas-Rijn. Researchcentrum voor Onderwijs en Arbeidsmarkt, Faculteit der Economische Wetenschappen. ROA Working Papers No. 6 https://doi.org/10.26481/umarow.1992006

Document status and date:

Published: 01/01/1992

DOI:

10.26481/umarow.1992006

Document Version:

Publisher's PDF, also known as Version of record

\section{Please check the document version of this publication:}

- A submitted manuscript is the version of the article upon submission and before peer-review. There can be important differences between the submitted version and the official published version of record.

People interested in the research are advised to contact the author for the final version of the publication, or visit the DOI to the publisher's website.

- The final author version and the galley proof are versions of the publication after peer review.

- The final published version features the final layout of the paper including the volume, issue and page numbers.

Link to publication

\footnotetext{
General rights rights.

- You may freely distribute the URL identifying the publication in the public portal. please follow below link for the End User Agreement:

www.umlib.nl/taverne-license

Take down policy

If you believe that this document breaches copyright please contact us at:

repository@maastrichtuniversity.nl

providing details and we will investigate your claim.
}

Copyright and moral rights for the publications made accessible in the public portal are retained by the authors and/or other copyright owners and it is a condition of accessing publications that users recognise and abide by the legal requirements associated with these

- Users may download and print one copy of any publication from the public portal for the purpose of private study or research.

- You may not further distribute the material or use it for any profit-making activity or commercial gain

If the publication is distributed under the terms of Article $25 \mathrm{fa}$ of the Dutch Copyright Act, indicated by the "Taverne" license above, 
MINIMUMLOON, UITKERINGSNIVEAU EN ARBEIDS-

SCHAARSTE IN DE EUREGIO MAAS-RIJN

ROA-W-1992/6

Petra Meyboom

Nederland in vergelijking met België en de Bondsrepubliek Duitsland

RESEARCHCENTRUM VOOR ONDERWIJS EN ARBEIDSMARKT

Faculteit der Economische Wetenschappen

Rijksuniversiteit Limburg

Maastricht, juni 1992 
Meyboom, Petra

Minimumloon, uitkeringsniveau en arbeidsschaarste in de Euregio Maas-Rijn: Nederland in vergelijking met België en de Bondsrepubliek Duitsland / Petra Meyboom.-

Maastricht: Researchcentrum voor Onderwijs en Arbeidsmarkt, Faculteit der Economische Wetenschappen, Rijksuniversiteit Limburg.- (ROA-W-1992/6, ISSN 0922-4645)

Met lit.opg.

ISBN 90-5321-087-3 in ringband

Trefw.; minimuminkomens; Nederland; onderzoek / werkgelegenheid; Nederland; onderzoek. 


\section{INHOUDSOPGAVE}

VOORWOORD

1. INLEIDING 1

1.1. Onderzoeksopzet 1

1.2. Job Search theorie $\quad 2$

DEEL 1

2. MINIMUMLOONREGELINGEN 4

2.1. Nederland 4

2.2. België $\quad 4$

$\begin{array}{ll}\text { 2.3. Bondsrepubliek Duitsland } & 5\end{array}$

2.4. Een vergelijking van de minimumloonniveaus $\quad 5$

3. REGELINGEN SOCIALE MINIMUMUITKERINGEN 9

$\begin{array}{ll}3.1 \text { Nederland } & 9\end{array}$

$\begin{array}{lr}3.2 \text { België } & 9\end{array}$

$\begin{array}{ll}3.3 \text { Bondsrepubliek Duitsland } & 10\end{array}$

$\begin{array}{ll}3.4 & \text { Een vergelijking van de minimumuitkeringen } \\ \end{array}$

4. EEN INTERNATIONALE VERGELIJKING VAN DE AFSTANDEN TUSSEN MINIMUM$\begin{array}{ll}\text { LOON EN UITKERINGEN } & 14\end{array}$

4.1. Een vergelijking van de replacementratio's 14

$\begin{array}{lr}\text { 4.2. Conclusies } & 17\end{array}$

DEEL 2

5. DE EUREGIONALE ARBEIDSMARKT 18

5.1. De Euregio Maas-Rijn 18

$\begin{array}{ll}\text { 5.2. Beleidsvoering arbeidsbureaus } & 20\end{array}$

6. VACATUREPROBLEMATIEK 22

6.1. Openstaande vacatures $\quad 22$

6.2. Moeilijk vervulbare vacatures $\quad 27$

$\begin{array}{ll}\text { 6.3. Loonstructuren en de vacatureproblematiek } & 31\end{array}$ 
7.1. Werkloosheid in de Euregio Maas-Rijn

7.2. Werkloosheid en loonstructuren

8. GRENSARBEID $\quad 35$

8.1. Grensarbeid binnen de Euregio Maas-Rijn $\quad 35$

$\begin{array}{ll}\text { 8.2. Een vergelijking van de gemiddelde bruto lonen } & 37\end{array}$

9. CONCLUSIES 40

LITERATUUR

BIJLAGEN

A. LOONSTRUCTUUR $\quad 45$

B. VACATUREPROBLEMATIEK $\quad 56$

C. WERKGELEGENHEID

D. GRENSARBEID 


\section{VOORWOORD}

Dit rapport is het resultaat van een stage uitgevoerd bij het Ministerie van Sociale Zaken en Werkgelegenheid, Directoraat-Generaal voor Algemene Beleidsaangelegenheden, in het kader van mijn studie algemene economie aan de Rijksuniversiteit Limburg. Het onderzoek is uitgevoerd door P. Meyboom in de periode februari - april 1992 en stond onder de begeleiding van drs. R.W.H.M. Lammers (Ministerie van Sociale Zaken en Werkgelegenheid) en dr. A. de Grip (Researchcentrum voor Onderwijs en Arbeidsmarkt, Rijksuniversiteit Limburg). Voor het tot stand komen van dit onderzoeksverslag is geput uit verschillende bronnen. De achterin opgenomen bronvermeldingen geven een overzicht van de geraadpleegde literatuur, artikelen, folders en dergelijke. Daarnaast is dank verschuldigd aan de volgende personen, waarmee gesprekken hebben plaatsgevonden:

- F. Aarts, Euregioconsulent Arbeidsbureau Heerlen;

- G.C.S. Braafheid, Medewerker Statistiek en Documentatie Regionaal Bureau voor de Arbeidsvoorziening, Maastricht;

- J. Haagdorens, Hoofd Studiedienst Provinciaal Christelijk Vakverbond Limburg, Hasselt;

- P.C.M. Hanraets, onderzoeker Economisch Technologisch Instituut Limburg;

- L. Jorissen, Bestuurssecretaris-economist Vlaamse Dienst voor Arbeidsbemiddeling en Beroepsopleiding, Tongeren;

- K. Kever, Pressesprecher Arbeitsamt Aachen;

- P. Meens, Abschnittleiter in der Arbeitsvermittlung Arbeitsamt Aachen;

- M.A.F. Soeren, Hoofd Personeelsvoorziening/plaatsvervangend directeur Arbeidsbureau Westelijke Mijnstreek, Sittard. 


\section{INLEIDING}

\subsection{Onderzoeksopzet}

Het inkomens- en werkgelegenheidsbeleid is nog steeds een belangrijk aandachtsveld voor de Nederlandse overheid. Met verschillende beleidsinstrumenten wordt getracht om tot een goede inkomensverdeling te komen en de werkgelegenheid te bevorderen. Momenteel dreigt de werkgelegenheidsgroei echter weer te stagneren. $\mathrm{Er}$ wordt nogal eens beweerd dat de uitkeringsniveaus in Nederland te hoog zouden zijn, waardoor het voor sommigen niet aantrekkelijk is zich op de arbeidsmarkt te begeven. De afstand tussen het eventueel te verdienen loon en het uitkeringsniveau kan in dat geval bepalend zijn voor de motivatie om aan het arbeidsproces deel te nemen. lemand die er financieel niet of nauwelijks op vooruit gaat na het accepteren van een baan, bedenkt zich wel twee keer alvorens aan het werk te gaan.

Door de bestaande Nederlandse loonstructuur in internationaal perspectief te plaatsen, wordt in deze studie onderzocht of de uitkeringsniveaus in vergelijking met de beide buurlanden inderdaad hoog zijn en/of de afstand tussen de lonen en uitkeringen afwijkend is. Daarbij is het verschil tussen de loon- en uitkeringsniveaus waarschijnlijk vooral voor arbeid op minimumloonniveau bepalend, omdat op dit niveau de afstand het kleinst zal zijn. Indien de relatieve afstanden tussen de minimumloon- en uitkeringsniveaus in Nederland klein zijn, kunnen conform de "job search"theorie bepaalde arbeidsmarkteffecten optreden. Deze effecten komen mogelijk tot uitdrukking in het tegelijkertijd optreden van vacature- en werkloosheidsproblemen.

In het eerste deel van deze studie wordt een internationale vergelijking van de Nederlandse minimumloon- en uitkeringsniveaus met de Belgische en Duitse niveaus gemaakt (respectievelijk hoofdstuk 2 en 3). Daarna wordt de afstand tussen het netto minimumloon- en uitkeringsniveau in Nederland door een vergelijking van zogenaamde replacementratio's in internationaal perspectief geplaatst (hoofdstuk 4). Op basis van deze bevindingen wordt een aantal mogelijke gevolgen voor de Nederlandse arbeidsmarkt geformuleerd. In de bijlage A die bij deel 1 hoort, staan alle tabellen met de minimumloon- en uitkeringsbedragen en de berekende replacementratio's. Om de bijlage zelfstandig leesbaar te houden, zijn enkele tabellen die in de tekst opgenomen zijn, ook in de bijlage geplaatst.

Het tweede deel van het verslag behandelt de vacature- en werkloosheidsproblematiek ten einde een mogelijke relatie met de bestaande loonstructuur te kunnen leggen. Een analyse van de eventuele effecten richt zich op de arbeidsmarkt in de Euregio Maas-Rijn ${ }^{1}$, één arbeidsmarkt aangrenzende aan Nederland, België en de Bondsrepubliek Duitsland, waardoor het mogelijk is de effecten van de verschillende loonstructuren te onderscheiden in Nederland, België en de Bondsrepubliek Duitsland te traceren.

1. In hoofdstuk 5 wordt duidelijk welk gebied precies wordt beschouwd. 
Hoofdstuk 5 geeft eerst een summier overzicht van enkele (economische) kenmerken van de Euregio Maas-Rijn, waarna nader wordt ingegaan op de vacatureproblematiek (hoofdstuk 6) en de werkloosheid (hoofdstuk 7). De vacatureproblemen worden onderscheiden naar openstaande vacatures (paragraaf 6.2) en moeilijk vervulbare vacatures (paragraaf 6.3) ingedeeld naar beroepsgroep en kwalificatieniveau. Op basis van een indeling naar kwalificatievereisten wordt getracht een relatie met het minimumloonniveau te leggen. Met name de vacatures voor laaggeschoolden zijn immers van belang voor de arbeidsmarktsituatie op minimumloonniveau.

In hoofdstuk 7 wordt eerst met behulp van werkloosheidsgegevens voor de Euregio Maas-Rijn een relatie gelegd tussen de bestaande (jeugd)werkloosheid en de berekende replacementratio's in het eerste deel van het verslag. Hoofdstuk 8 beschrijft de omvang van de grensarbeid en de richting van de pendelstromen binnen de Euregio Maas-Rijn. Daarbij wordt ook gekeken naar een eventuele samenhang met verschillen in de arbeidsmarktsituatie in de drie deelregio's. Het verslag wordt afgesloten met enkele conclusies met betrekking tot de gevolgen van de Nederlandse loonstructuur, de relatieve afstand tussen het netto minimumloon en het netto uitkeringsniveau en de vacature- en werkloosheidsproblematiek.

\subsection{Job Search Theorie}

Een theorie die in gaat op het verschil tussen minimumloon en minimumuitkering is de zogenaamde "job search" theorie (zie bijvoorbeeld Groot en Jehoel-Gijsbers (1990). Volgens deze 'zoektheorie' heeft een te gering verschil tussen de minimumlonen en sociale uitkeringen een negatief effect op de werkgelegenheid. Verondersteld wordt dat de motivatie van individuen om een baan te zoeken en te accepteren daalt met het verkleinen van het genoemde verschil. Achtergrond hiervan is het dalen van de "opportuniteitskosten" van het werkloos zijn, als gevolg van het recht op een sociale uitkering, waardoor het aantrekkelijk wordt de baanloze situatie te handhaven.

Volgens dezelfde theorie zal iemand pas een baan accepteren wanneer het aangeboden loon groter of gelijk is aan het reserveringsloon. Dit is de minimumloonhoogte waarbij een individu bereid is aan het arbeidsproces deel te nemen. Het niveau van het reserveringsloon wordt bepaald door het punt waar de marginale kosten van het zoeken naar een baan en de marginale opbrengsten van het accepteren van een baan aan elkaar gelijk zijn ${ }^{2}$. Indien het verschil tussen minimumloon en sociale uitkering slechts klein is, is het mogelijk dat het reserveringsloon voor veel potentieel werkenden hoger zal liggen dan het minimumloon. De reden hiervoor is dat de gemiste opbrengsten van het niet accepteren van de aangeboden baan relatief klein zijn, als gevolg van de relatief hoge uitkering.

Wanneer de reserveringslonen voor laag geschoolden inderdaad boven het minimumloon liggen, kan dit tot uitdrukking komen in het tegelijkertijd optreden van enerzijds openstaande en moeilijk vervulbare vacatures voor laag opgeleide arbeidskrachten en anderzijds de werkloosheid onder

2. Zie bv. Hamermesh \& Rees (1988). 
$-3-$

laag geschoolden. Er bestaan in dat geval voor potentiële werknemers op minimumloonniveau weinig prikkels om een baan te zoeken, waardoor vacatures op dit niveau open zullen blijven en moeilijk vervulbaar zullen zijn en de werkloosheid in de laag geschoolden relatief hoog zal zijn.

Wanneer de reserveringslonen voor laaggeschoolden inderdaad boven het minimumloon liggen, kan dit tot uitdrukking komen in het tegelijkertijd optreden van enerzijds openstaande en moeilijk vervulbare vacatures voor laag opgeleide arbeidskrachten en anderzijds werkloosheid onder laaggeschoolden. 


\section{DEEL 1}

\section{MINIMUMLOONREGELINGEN}

\subsection{Nederland}

Nederland behoort sinds invoering in 1969 tot de groep landen waarvoor de minimumloonregeling onder een wettelijke regeling valt ${ }^{3}$. Volwassenen vanaf 23 jaar komen er voor in aanmerking. Jongeren ontvangen een minimumjeugdloon, dat met een vast percentage aan het minimumloon gekoppeld is; dit wordt jeugdloonstaffeling genoemd. In 1980 verving de Wet Aanpassingsmechanismen (WAM) de halfjaarlijkse indexering van het minimumloon aan de regelingslonen. Volgens de WAM worden het minimumloon en de loongerelateerde uitkeringen ieder half jaar automatisch aangepast aan de ontwikkelingen van de regelingslonen, nadat ze voor enkele componenten zijn geschoond. Daarbij moet eens in de drie jaar bekeken worden hoe de feitelijk verdiende lonen en regelingslonen zich verhouden ten opzichte van de minimumlonen en/of er reden is om de minimumlonen incidenteel te verhogen. Het Ministerie van Sociale Zaken en Werkgelegenheid is verplicht hier advies over in te winnen bij de SER. Inmiddels is de WAM per januari 1992 vervangen door de Wet Koppeling op Afstand (WKA); binnen deze wet is het mogelijk om af te wijken van de strikte koppeling tussen minimumlonen en regelingslonen.

\subsection{België}

In België ${ }^{4}$ wordt het wettelijk minimumloon afgeleid uit de CAO's. Eerst wordt via het arbeidsovereenkomstenoverleg over de minimumlonen onderhandeld. Vervolgens worden deze wettelijk vastgesteld door de Nationale Adviesraad. Het minimumloon krijgt dus pas in de "tweede fase" de wettelijke status (Van den Heuvel, 1992).

In februari 1975 werd een overeenkomst gesloten tussen werkgevers en werknemers over de herinvoering van het nationaal geldend gegarandeerd minimumloon:"Le Revenu Minimum Mensuel Moyen Garanti (RMMMG)". Het doel van het "gewaarborgde" minimumloon is het aangeven van een ondergrens voor het vaststellen van de minimumbeloningen in de CAO's. Werknemers ouder dan 21 jaar komen voor het vastgestelde bedrag in aanmerking. In aansluiting daarop wordt het minimumjeugdloon op dezelfde wijze als in Nederland, via een staffelingssysteem, berekend. Verder kan twee maal per jaar een aanpassing van de minimumlonen plaatsvinden op basis van de ontwikkeling van het prijsindexcijfer van de consumptie. Daarvoor is vereist dat de prijzen de voorafgaande vier maanden met minimaal $2 \%$ gestegen zijn.

3. Andere landen in de EG zijn: Spanje, Portugal, Frankrijk en Luxemburg.

4. Evenals in Griekenland. 


\subsection{Bondsrepubliek Duitsland}

In de Bondsrepubliek Duitsland geldt geen wettelijk nationaal minimumloon, maar wel een zogenaamd formeel minimumloon (Van den Heuvel, 1992). Sinds 1952 geldt de Gesetz über die Festsetzung von Minimumlöhne naast de jaarlijkse (bedrijfstakgewijze) CAO overeenkomsten tussen werkgevers- en werknemersorganisaties. Op basis van deze "Gesetz" kan de Minister van Arbeid bepaalde bedrijfstakken wijzen op de minimum arbeidsvoorwaarden, waaronder het minimumloon. De bedrijfstakken zijn dan verplicht hierover afspraken te maken. Door het hoge loonniveau in de bedrijfstak-CAO's is dit echter (nog) niet aan de orde geweest. Het minimumjeugdloon (berekend op basis van staffelingspercentages) geldt voor jongeren tot 21 jaar die hun leerlingentijd nog niet hebben voltooid. Na voltooiing ontvangen ze het minimumloon voor volwassenen (Korpel et. al., 1989).

\subsection{Een vergelijking van de minimumloonniveaus}

In alle drie de landen worden de minimumjeugdlonen berekend aan de hand van staffelingspercentages van het minimumloon voor volwassenen. In tabel 1 worden de staffelingspercentages die in de drie landen gehanteerd worden vergeleken.

Tabel 1. Staffelingspercentages ter bepaling van het minimumjeugdloon

\begin{tabular}{lccc}
\hline Leeftijd & $\begin{array}{c}\text { Nederland } \\
\%\end{array}$ & $\begin{array}{c}\text { België"* } \\
\%\end{array}$ & $\begin{array}{c}\text { BRD** } \\
\%\end{array}$ \\
\hline & & & \\
15 & 30.0 & 62.5 & 90 \\
17 & 34.5 & 70.0 & 90 \\
18 & 39.5 & 77.5 & 90 \\
19 & 45.5 & 85.0 & 95 \\
20 & 52.5 & 92.5 & 100 \\
21 & 61.5 & 100.0 & \\
22 & 72.6 & &
\end{tabular}

Bron: K. van den Heuvel (1992) Minimumbeloningen in de Europese Gemeenschap. Bijlage, p.10, 19; en gegevens Statistisches Bundesamt, Wiesbaden.

* Gelden sinds 1983.

** Sinds 1989 .

*** Volgens het "Lohnvertrag Eisen- Metall- und Elektroindustrie NRW, de belangrijkste Duitse CAO per 01-01-1992 in werking getreden. De staffelingspercentages in de BRD worden per CAO vastgesteld. Zoals eerder vermeld wijkt het minimumjeugdloon alleen gedurende de leerlingentijd af van het minimumloon voor volwassenen.

De staffelingspercentages zijn in Nederland het laagst en bovendien treedt het minimumloon voor volwassenen er pas op relatief hoge leeftijd in werking. Hieronder zal worden ingegaan op de uitwerking van de staffelingspercentages op de minimumloonniveaus voor jongeren. 
De verschillende bedragen van het minimumloon kunnen vergeleken worden op basis van koopkrachtpariteiten ${ }^{5}$. Voor het maken van een vergelijking van de verschillende niveaus van de minimumlonen in Nederland, de Bondsrepubliek Duitsland en België wordt voor wat Duitsland betreft uitgegaan van de laagste loongroep in de metaalsector ${ }^{6}$ in Nordrhein-Westfalen. Onder deze laagste loongroep valt enerzijds eenvoudige arbeid met een geringe lichamelijke belasting, die na een korte instructie is uit te voeren. Ook eenvoudige arbeid met een leertijd van maximaal vier weken, die tevens weinig lichamelijke inspanning vergt, valt onder deze laagste loongroep. De metaalindustrie blijkt in het algemeen niet veel af te wijken van de minimumlonen in de andere sectoren. Desondanks is geen sprake van een optimale vergelijking, wanneer het Nederlandse minimumloon wordt vergeleken met het laagste loon in de metaalsector in de BRD. Dat blijkt uit het feit dat het laagste CAO loon in de metaal in Nederland in 1990 zo'n $105.9 \%$ van het wettelijk minimumloon bedroeg (Van den Heuvel, 1992).

De tabellen 2 tot en met 4 geven een vergelijking van de netto minimumloonniveaus met behulp van indexcijfers met Nederland als basis ${ }^{7}$. De netto bedragen voor Nederland en België zijn via berekening van de af te dragen belasting en premies van de bruto bedragen afgeleid. Voor de Bondsrepubliek Duitsland is een grovere wijze gehanteerd: daarvoor is een inschatting gemaakt voor het verschil tussen het bruto en netto minimumloon.

Tabel 2. Netto minimumloonniveaus naar leeftijd voor alleenstaanden in België en Duitsland in vergelijking met Nederland, 1992 (indexcijfers; Nederland = 100)

\begin{tabular}{lcc}
\hline Leeftijd & België & BRD \\
\hline & & \\
16 & 165 & 197 \\
17 & 164 & 178 \\
18 & 161 & 159 \\
19 & 155 & 142 \\
20 & 146 & 131 \\
21 & 136 & 120 \\
22 & 121 & 105 \\
& 105 & 91
\end{tabular}

Bron: Bewerking van: Nederlandse bedragen, SZW; Belgische, Ministerie van Tewerkstelling en Arbeid, Belastingdienst; Duitse, Lohnvertrag Eisen-, Metall- und Elektroindustrie, Arbeitsamt Aachen.

5. Volgens de koopkrachtpariteitentheorie is de wisselkoersverhouding op lange termijn gelijk aan de verhouding van de nationale prijsniveaus. Wanneer een land een bepaald prijsvoordeel geniet ten opzichte van een ander land, zal via het saldo op de lopende rekening en een betalingsbalansonevenwichtigheid, een wisselkoersaanpassing plaatsvinden. Dit proces gaat door totdat de wisselkoersverhoudingen gelijk zijn aan de prijsverhoudingen. (Samuelson \& Nordhaus 1985)

6. Lohntarifvertrag für die Eisen-, Metal und Elektroindustrie.

7. De indexcijfers zijn berekend aan de hand van koopkrachtpariteiten van 1990, gecorrigeerd voor de inflatie van 1991. Zie verder bijlage A. 
Er is rekening gehouden met factoren als de gezinssituatie ${ }^{8}$. Tabel 2 toont de netto minimumloonniveaus voor alleenstaanden, tabel 3 voor echtparen en tabel 4 voor echtparen met twee kinderen. Daarbij is er van uitgegaan dat een echtpaar minimaal de 18 jarige leeftijd en een echtpaar met twee kinderen de 20 jarige leeftijd heeft bereikt. Wat de laatst genoemde leefsituatie aangaat is tevens aangenomen dat een echtpaar in de leeftijd van 20 tot en met 22 jaar kinderen heeft in de leeftijd van 0 tot 5 jaar; en een echtpaar van 23 jaar en ouder van 6 tot 12 jaar.

Tabel 2 laat zien dat de netto minimumjeugdlonen in Nederland duidelijk beneden de niveaus van België en de BRD te liggen. Die verschillen nemen af naarmate de leeftijd toeneemt. Alleen het minimumloon voor alleenstaanden van 23 jaar en ouder is in Duitsland lager dan in Nederland.

Tabel 3. Netto minimumloonniveaus naar leeftijd voor echtparen in België en Duitsland in vergelijking met Nederland, 1992 (indexcijfers; Nederland $=100$ )

\begin{tabular}{lcc}
\hline Leeftijd & België & BRD \\
\hline & & \\
18 & 143 & 142 \\
19 & 138 & 126 \\
20 & 132 & 119 \\
21 & 126 & 111 \\
22 & 114 & 99 \\
$\geq 23$ & 95 & 82
\end{tabular}

Bron: Bewerking van: Nederlandse bedragen, SZW; Belgische, Ministerie van Tewerkstelling en Arbeid, Belastingdienst; Duitse, Lohnvertrag Eisen-, Metall- und Elektroindustrie, Arbeitsamt Aachen.

Voor echtparen is het netto minimumjeugdloon in Nederland lager dan in België en in Duitsland. Alleen voor 22 jarigen valt het minimumloon in het laatstgenoemde land wat lager uit dan in Nederland. Het netto minimumloon voor volwassenen is in Nederland daarentegen juist hoger dan in de beide buurlanden (zie tabel 3).

Het netto minimumloon in Nederland voor echtparen met twee kinderen is lager dan in de Bondsrepubliek Duitsland en voor 20-23 jarigen ook lager dan in België. Alleen voor een Belgisch echtpaar met een kostwinner van 23 jaar en ouder en met twee kinderen is het netto minimumloon lager dan in Nederland (zie tabel 4).

In het voorgaande is duidelijk geworden dat de netto minimumjeugdlonen in Nederland voor de drie genoemde leefsituaties doorgaans lager zijn dan in België en de BRD. Een uitzondering daarop vormt een echtpaar met een kostwinner van 22 jaar zonder kinderen in Duitsland, waarvoor een lager minimumloonniveau geldt dan in Nederland. Voor volwassen alleenstaanden

8. In bijlage A wordt meer informatie gegeven over de bruto en netto minimumlonen. 
van 23 jaar en ouder is het netto minimumloon in Nederland lager dan in België, maar hoger dan in de BRD. Voor echtparen in dezelfde leeftijdscategorie zonder kinderen is het minimumloon in Nederland hoger dan in beide andere landen en voor echtparen met twee kinderen is het niveau hoger dan in België en lager dan in de BRD.

Tabel 4. Netto minimumloonniveaus naar leeftijd voor echtparen met 2 kinderen in België en Duitsland in vergelijking met Nederland, 1992 (indexcijfers; Nederland $=100$ )

\begin{tabular}{lcc}
\hline Leeftijd & België & BRD \\
\hline & & 179 \\
20 & 131 & 161 \\
21 & 125 & 144 \\
22 & 114 & 118 \\
\hline
\end{tabular}

Bron: Bewerking van: Nederlandse bedragen, SZW; Belgische, Ministerie van Tewerkstelling en Arbeid, Belastingdienst; Duitse, Lohnvertrag Eisen-, Metall- und Elektroindustrie, Arbeitsamt Aachen. 
$-9-$

\section{REGELINGEN SOCIALE MINIMUMUITKERINGEN}

\subsection{Nederland}

"ledereen die niet in staat is om (volledig) in zijn of haar inkomen te voorzien, i.c. wiens inkomen beneden het voor hem of haar geldende norminkomen ligt, kan een beroep doen op de Algemene Bijstandswet (ABW), waaronder ook werklozen die geen aanspraak (meer) kunnen maken op een uitkering krachtens de Werkloosheidswet (WW)", (Korpel et al., 1989). De ABW fungeert op deze wijze als vangnet in het Nederlandse sociale zekerheidsstelsel.

Het niveau van de uitkeringen is afhankelijk van leeftijd, leefsituatie en andere inkomsten. Naast bijvoorbeeld de ABW uitkering en de daarvan afgeleide RWW (Rijksgroepregeling Werkloze Werknemers) $^{9}$ zijn er nog andere inkomsten mogelijk in de vorm van toeslagen op de uitkering, incidentele uitkeringen, kinderbijslag en huursubsidie. Werklozen die voor hun werkloosheid een voldoende aantal weken (en aantal uren per week) gewerkt hebben, komen in aanmerking voor een uitkering volgens de Werkloosheidswet. Deze basisuitkering wordt een half jaar verstrekt. Daarnaast zijn er een aantal mogelijkheden om voor een verlengde uitkering in aanmerking te komen. Na afloop van deze uitkering(en) komt de werkloze gedurende een jaar in aanmerking voor een vervolguitkering. De basis- en verlengde uitkering bedragen samen $70 \%$ van het dagloon en de vervolguitkering $70 \%$ van het wettelijk minimumloon. $\mathrm{Na}$ beëindiging van het recht op een vervolguitkering komt een werkloze in aanmerking voor een Algemene Bijstandsuitkering. Via de WKA zijn de uitkeringen aan de minimumlonen en daarmee aan de regelingsIonen gekoppeld. Hiermee volgt de ontwikkeling van de uitkeringen de ontwikkeling van de Ionen in het bedrijfsleven.

\subsection{België}

In België komt men in aanmerking voor een uitkering als men niet over voldoende middelen van bestaan beschikt en deze door middel van arbeid of andere middelen niet kan verwerven. Het niveau van de uitkeringen is afhankelijk van de leefsituatie; echtparen/samenwonenden ontvangen $100 \%$ en alleenstaanden $72 \%$ van het laatstverdiende loon. Daarbij kan de uitkering op minimumniveau in bepaalde situaties aangevuld worden. De bedragen worden aangepast aan het prijsindexcijfer van de gezinsconsumptie. Het bedrag van de werkloosheidsuitkering is afhankelijk van de leefsituatie, leeftijd en het arbeidsverleden. Na deze werkloosheidsuitkering anderhalf jaar te hebben ontvangen komen werklozen in de werkloosheidsbijstand. Gezinshoofden krijgen dan 60\% van het laatstverdiende loon (met een bepaald minimum) en samenwonenden en alleenstaanden een vast bedrag per dag ("allocation journaliere"). De regelingen voor schoolverlaters en langdurig werklozen vallen dus niet zoals in Nederland (RWW) onder de bijstandsregelingen, maar onder de werkloosheidsvoorzieningen. Er wordt op deze wijze onderscheid gemaakt tussen de "gewone" bijstandsuitkering en de uitkering voor

9. De RWW voorziet in de noodzakelijke kosten van levensonderhoud, wanneer geen andere regeling van toepassing is. 
werklozen. Beschikt men als werkloze niet over een (voldoende) arbeidsverleden, dan ontvangt men een wachtuitkering.

Onder het zogenaamde "assistance sociale" vallen het recht op het bestaansminimum en de kinderbijslag. Men heeft recht op het bestaansminimum indien men (Lammertyn, 1987):

- geen toereikende bestaansmiddelen heeft (inkomens-en vermogenstoets);

- niet in staat is door eigen inspanning voldoende bestaansmiddelen te verwerven, maar wel blijk geeft van bereidheid hiertoe, tenzij dit om gezondheids- of billijkheidsredenen onmogelijk is (dit is ook van toepassing op de eventuele echtgenoot);

- niet in staat is op een andere wijze wel toereikende bestaansmiddelen te verwerven (bijvoorbeeld door een andere uitkering aan te vragen);

- 21 jaar of ouder is.

\subsection{Bondsrepubliek Duitsland}

In de BRD komen diegenen die niet of onvoldoende in staat zijn om door middel van een eigen inkomen of vermogen in hun eigen levensonderhoud te kunnen voorzien in aanmerking voor een uitkering. Daarbij bestaat er een zogenaamde basisuitkering waarop een toeslag mogelijk is ${ }^{10}$. Deze "Sozialhilfe" heeft de vangnetfunctie, vergelijkbaar met de Nederlandse ABW, deze omvat:

- hulp in geval van bepaalde omstandigheden, zoals ziekte;

- aanvulling in de kosten van levensonderhoud.

De hoogte van de uitkering is afhankelijk van een bestedingspakket (Warenkorb) dat op basis van budgetonderzoek wordt vastgesteld en waarvan de bedragen per deelstaat kunnen verschillen. De niveaus van de uitkeringen worden net beneden de laagste salarisniveaus (inclusief kinderbijslag en huurtoeslag) vastgesteld. Een eventuele aanpassing van de uitkeringen vindt plaats op basis van het prijsindexcijfer van de "Warenkorb".

De uitkeringsbedragen worden individueel vastgesteld, maar zijn wel afhankelijk van de leefsituatie. Wat de werkloosheidsregelingen betreft bestaat het verzekeringsstelsel uit een werkloosheidsverzekering ("Arbeitslosengeld") en een werkloosheidsbijstand ("Arbeitslosenhilfe"). De eerste uitkering ontvangen mensen die een bepaalde periode gewerkt hebben en een bijdrage in de verzekeringskas gestort hebben. De duur van de te ontvangen uitkering is afhankelijk van het arbeidsverleden en de leeftijd van de werkloze. De "Arbeitslosenhilfe" geldt voor langdurig werklozen tot aan de 65 jarige leeftijd. Voorwaarde is dat men een bepaalde periode gewerkt moet hebben. Wel wordt jaarlijks bekeken of men nog steeds voldoet aan de voorwaarden voor het verkrijgen van die "Arbeitslosenhilfe". Het uitkeringsniveau wordt bepaald op basis van een percentage van het laatstverdiende loon.

10. Bijvoorbeeld: 65 +ers krijgen een toeslag van $20 \%$; eenoudergezinnen met 2 of 3 kinderen $20 \%$ en gehandicapten $40 \%$. 


\subsection{Een vergelijking van de minimumuitkeringen}

In deze paragraaf zal een vergelijking worden gemaakt van de niveaus van de minimumuitkeringen voor Nederland, België en Duitsland. Om tot een vergelijking te kunnen komen is gekozen voor die regelingen in de betreffende landen, die elkaar zoveel mogelijk benaderen en relevant zijn voor het potentiële aanbod op de arbeidsmarkt op minimumlooniveau.

Voor Nederland wordt het niveau van de ABW weergegeven, eventueel aangevuld met een bedrag aan kinderbijslag. Maar het bedrag aan huursubsidie en enkele andere inkomensafhankelijke inkomensbronnen zijn weggelaten, omdat deze bedragen afhangen van sterk uiteenlopende factoren binnen een huishouden en daardoor moeilijk te kwantificeren zijn. Voor wat België betreft worden twee bedragen gegeven: de gewone bijstand en de "bijstand"11 voor werklozen. De uitkering voor werklozen is een minimumuitkering die werklozen op den duur onbeperkt (onder een aantal voorwaarden, waaronder stempelcontrole) blijven ontvangen. Voor werkloze jongeren van 18 en 19 jaar is hier aangenomen dat ze een wachtuitkering ontvangen, omdat werkloze schoolverlaters in België zonder arbeidsverleden gewoonlijk een dergelijke uitkering krijgen ${ }^{12}$. De uitkeringsbedragen worden eventueel aangevuld met kinderbijslag. In de BRD wordt rekening gehouden met woonkostenvergoedingen het zogenaamde "Wohngeld". Uitkeringsgerechtigden en mensen met de laagste inkomens ontvangen een vergoeding voor de te maken woonkosten, met daarbij eventueel een bedrag voor de verwarmingskosten, die gemiddeld zo'n $25 \%$ van het "Wohngeld" uitmaken. De totale vergoeding is afhankelijk van de individuele woon-, leef- en inkomenssituatie en is daarom moeilijk vast te stellen. Hier zal worden uitgegaan van de maximale inkomens waarvoor een woonvergoeding mogelijk is en het gemiddelde bedrag aan "Wohngeld". De verwarmingskosten zijn daarbij echter buiten beschouwing gelaten. Op basis hiervan is een gemiddeld bedrag aan "Wohngeld" toegerekend aan uitkeringsgerechtigden en echtparen met twee kinderen met genoemd inkomensniveau in de BRD (Wirtschaft und Statistik, 1991). Uit onderzoek is gebleken dat uitkeringsgerechtigden in de BRD uiteindelijk $20^{\prime} n 27 \%$ van hun inkomsten aan het wonen besteden (Hills et. al., 1990). Dit is dan ook de reden dat het "Wohngeld" in de analyse wordt betrokken: het bedrag vormt een vrij groot gedeelte van het besteedbaar inkomen. De huursubsidie en kinderbijslag wordt volgens het Duitse systeem van de uitkering afgetrokken. Derhalve worden die niet in de berekening betrokken ${ }^{13}$. Ook in de BRD geldt een zogenaamde werkloosheidsbijstand. Deze "Arbeitslosenhilfe" is echter afhankelijk van het vroegere inkomen

11. Deze uitkering wordt geen 'bijstand' genoemd: het betreft immers een minimumuitkering voor werklozen. Door de onbeperkte uitkeringsduur is de uitkering echter vergelijkbaar met de Nederlandse bijstandsuitkering.

12. Een werkloze van 18-26 jaar moet voor aanvraag van een werkloosheidsuitkering bewijzen, gedurende de 10 maanden voor aanvraag ten minste 150 dagen arbeid in loondienst te hebben verricht. Werklozen jongeren van 18 en 19 jaar voldoen doorgaans niet aan deze eis.

13. "Minimumloners" ontvangen wel kinderbijslag, deze vitkering is derhalve wel in de analyse betrokken. 
en daarom moeilijk weer te geven.

Uit het voorgaande blijkt, zoals ook in Korpel et al. (1989) wordt aangegeven, dat een internationale vergelijking van de netto minimumuitkeringen niet zonder meer plaats kan vinden. Zo zullen de besteedbare inkomens in Nederland en de BRD in werkelijkheid nogal eens hoger zijn dan uit de tabellen 5-7 blijkt: in Nederland door het buiten beschouwing laten van de huursubsidie en in de BRD door het niet beschouwen van bijzondere aanvullingen voor uitkeringsgerechtigden in bepaalde situaties. Dat laatste geldt in mindere mate ook voor mensen met een minimumuitkering in België. Desondanks kunnen de indexcijfers in de tabellen 5 tot en met 7 een indruk geven over een vergelijking van de minimumuitkeringen van Nederland, België en de BRD.

Evenals in hoofdstuk 2 werd gedaan voor de minimumloonniveaus, worden hier de verschillende uitkeringsniveaus voor drie leefsituaties weergegeven: voor een alleenstaande (tabel 5), een echtpaar zonder kinderen (tabel 6) en een echtpaar met twee kinderen (tabel 7).

Tabel 5. Netto minimumuitkeringsniveaus naar leeftijd voor alleenstaanden in België en Duitsland in vergelijking met Nederland, 1992 (indexcijfers; Nederland = 100)

\begin{tabular}{|c|c|c|c|}
\hline \multirow[t]{2}{*}{ Leeftijd } & \multicolumn{2}{|c|}{ België } & \\
\hline & (bijstand) & (werkl.) & \\
\hline 18 & 115 & 74 & 80 \\
\hline 19 & 115 & 74 & 80 \\
\hline 20 & 115 & 120 & 80 \\
\hline 21 & 110 & 115 & 76 \\
\hline 22 & 96 & 100 & 66 \\
\hline$\geq 23$ & 80 & 84 & 56 \\
\hline
\end{tabular}

Bron: Bewerking van: Nederlandse bedragen, SZW; Belgische, Ministerie van Tewerkstelling en Arbeid, Belastingdienst; Duitse, Lohnvertrag Eisen-, Metall- und Elektroindustrie, Arbeitsamt Aachen.

Uit tabel 5 blijkt dat de Nederlandse uitkeringsniveaus voor alleenstaanden aanmerkelijk hoger zijn dan in de Bondsrepubliek Duitsland en ook hoger liggen dan de gewone bijstand en de werkloosheidsbijstand voor 23 jarigen en ouder in België. Behalve in het geval van de wachtgelduitkeringen (18 en 19 jarigen) in België zijn de bijstandsuitkeringen in dit land voor jeugdigen echter hoger dan in Nederland.

Tabel 6 laat zien dat de netto minimumuitkeringen voor echtparen zonder kinderen in Nederland voor alle leeftijdscategorieën aanmerkelijk hoger zijn dan in de beide buurlanden.

Voor echtparen met twee kinderen zijn de netto minimumuitkeringen in Nederland hoger dan de Belgische bijstandsuitkering en de Duitse minimumuitkering. De Belgische werkloosheidsbijstand bevindt zich voor echtparen met twee kinderen op vergelijkbaar niveau met Nederland (zie tabel 7). 
Tabel 6. Netto minimumuitkeringsniveaus naar leeftijd voor echtparen 1992 (indexcijfers; Nederland = 100)

\begin{tabular}{|c|c|c|c|}
\hline \multirow[t]{2}{*}{ Leeftijd } & \multicolumn{2}{|c|}{ België } & \multirow[t]{2}{*}{ BRD } \\
\hline & (bijstand) & (werkl.) & \\
\hline 18 & 75 & 82 & 64 \\
\hline 19 & 75 & 82 & 64 \\
\hline 20 & 75 & 82 & 64 \\
\hline 21 & 75 & 82 & 64 \\
\hline 22 & 75 & 82 & 64 \\
\hline$\geq 23$ & 75 & 82 & 64 \\
\hline
\end{tabular}

Tabel 7. Netto minimumuitkeringsniveaus naar leeftijd voor echtparen met 2 kinderen 1992 indexcijfers; Nederland $=100$ )

\begin{tabular}{|c|c|c|c|}
\hline \multirow[t]{2}{*}{ Leeftijd } & \multicolumn{2}{|c|}{ België } & \multirow[t]{2}{*}{ BRD } \\
\hline & (bijstand) & (werkl.) & \\
\hline 20 & 96 & 102 & 82 \\
\hline 21 & 96 & 102 & 82 \\
\hline 22 & 96 & 102 & 82 \\
\hline$\geq 23$ & 93 & 100 & 84 \\
\hline
\end{tabular}

Bron: Bewerking van: Nederlandse bedragen, SZW; Belgische, Ministerie van Tewerkstelling en Arbeid, Belastingdienst; Duitse, Lohnvertrag Eisen-, Metall- und Elektroindustrie, Arbeitsamt Aachen.

In dit hoofdstuk zijn de (minimum)uitkeringsniveaus voor een drietal verschillende leefsituaties in Nederland, België en de BRD met elkaar vergeleken. Daarbij kwam naar voren dat de uitkeringsbedragen in Nederland hoger zijn dan in de BRD. Voor de Belgische bijstandsuitkering geldt hetzelfde met uitzondering van alleenstaande jongeren tot 22 jaar. De Belgische werkloosheidsbijstandsuitkering voor echtparen zonder kinderen is echter lager dan in Nederland, voor echtparen met twee kinderen zijn de bedragen ongeveer te vergelijken met Nederland en voor alleenstaanden is de wachtgelduitkering voor 18 en 19 jarigen en de werkloosheidsbijstand voor 23 jarigen en ouder lager dan de Nederlandse uitkeringsbedragen. Voor alleenstaanden van 20 en 21 jaar is de werkloosheidsbijstandsuitkering in België hoger dan in Nederland. 


\section{EEN INTERNATIONALE VERGELIJKING VAN DE AFSTANDEN TUSSEN MINIMUMLOON EN UITKERINGEN}

\subsection{Een vergelijking van de replacementratio's}

Het verschil tussen het minimumloonniveau en het bedrag van de minimumuitkering kan tot bepaalde reacties op de arbeidsmarkt leiden. Volgens de in hoofdstuk 1 genoemde "search theorie" kan een te klein verschil tussen de beide bedragen leiden tot een geringere arbeidsparticipatie. In dit hoofdstuk wordt ingegaan op de afstanden tussen het netto minimumloon en de netto minimumuitkering in Nederland, België en de BRD. De vergelijking van de afstanden tussen minimumloon en uitkering vindt conform de "search theorie" plaats op basis van de netto bedragen. De afstanden zijn daarbij via zogenaamde replacementratio's weergegeven. Deze replacementratio's zijn in overeenstemming met de "job search"theorie gedefinieerd als "de verhouding tussen de uitkeringshoogte en het normaal te verdienen loon" (Groot \& Jehoel-Gijsbers, 1990). De analyse richt zich hier op de "onderkant van de arbeidsmarkt" en gaat derhalve uit van een replacementratio gebaseerd op het minimumuitkerings- en het minimumloonniveau. Tabel 8 geeft behalve de replacementratio's tevens de absolute afstanden tussen het netto minimumloon en netto uitkering weer in guldens. Deze zijn via koopkrachtpariteiten van 1990, gecorrigeerd voor de inflatie van 1991 , berekend ${ }^{14}$.

Tabel 8. Replacementratio's (R) en absolute afstanden (in guldens) tussen minimumloon en minimumuitkering voor alleenstaanden (1992)

\begin{tabular}{|c|c|c|c|c|c|c|c|c|}
\hline \multirow[t]{3}{*}{ Leeftijd } & \multirow{2}{*}{\multicolumn{2}{|c|}{ Nederland }} & \multicolumn{4}{|c|}{ België } & \multirow{2}{*}{\multicolumn{2}{|c|}{ BRD }} \\
\hline & & & & tand) & & erkl.) & & \\
\hline & $\mathrm{R}$ & $f$ & $R$ & $f$ & $R$ & $f$ & $R$ & $f$ \\
\hline 18 & 1.03 & $(-28)$ & 0.74 & $(336)$ & 0.47 & (684) & 0.52 & (622) \\
\hline 19 & 0.92 & (71) & 0.68 & $(445)$ & 0.44 & (793) & 0.52 & (622) \\
\hline 20 & 0.81 & (198) & 0.64 & (547) & 0.67 & $(502)$ & 0.49 & (694) \\
\hline 21 & 0.73 & $(311)$ & 0.60 & $(650)$ & 0.63 & (605) & 0.47 & (766) \\
\hline 22 & 0.73 & (359) & 0.58 & (688) & 0.61 & (643) & 0.47 & (766) \\
\hline$\geq 23$ & 0.76 & $(378)$ & 0.58 & (688) & 0.61 & $(643)$ & 0.47 & (766) \\
\hline
\end{tabular}

Bron: Bewerking van: Nederlandse bedragen, SZW; Belgische, Ministerie van Tewerkstelling en Arbeid, Belastingdienst; Duitse, Lohnvertrag Eisen-, Metall- und Elektroindustrie, Arbeitsamt Aachen.

De afstand tussen het netto minimumloon en de netto minimumuitkering voor alleenstaanden is voor Nederland het kleinst, de replacementratio is immers groter dan in beide andere landen. Dit geldt voor alle leeftijdscategorieën. Wel is de replacementratio in Nederland, overigens niet als

14. De koopkrachtpariteiten van 1990 zijn de meest recente gegevens. Door aanpassing aan de inflatie over 1991 zijn de pariteiten geactualiseerd. 
in België en Duitsland voor jeugdigen groter dan voor volwassenen. Voor 18 jarigen is de afstand tussen minimumloon en uitkering zelfs negatief ${ }^{15}$.

Tabel 9 geeft de afstand tussen het netto minimumloon en de netto uitkering weer voor een echtpaar zonder kinderen.

Tabel 9. Replacementratio's (R) en absolute afstanden (in guldens) tussen minimumloon en minimumuitkering voor echtparen (1992)

\begin{tabular}{|c|c|c|c|c|c|c|c|c|}
\hline \multirow[t]{3}{*}{ Leeftijd } & \multicolumn{2}{|c|}{ Nederland } & \multicolumn{4}{|c|}{ België } & \multicolumn{2}{|c|}{ BRD } \\
\hline & & & & stand) & & erkl.) & & \\
\hline & $R$ & $f$ & $R$ & $f$ & $R$ & $f$ & $\mathbf{R}$ & $f$ \\
\hline 18 & 1.89 & $(-805)$ & 0.99 & (14) & 1.09 & $(-111)$ & 0.85 & (191) \\
\hline 19 & 1.67 & $(-690)$ & 0.91 & (123) & 1.00 & $(-2)$ & 0.85 & (191) \\
\hline 20 & 1.50 & $(-572)$ & 0.85 & (226) & 0.93 & $(100)$ & 0.81 & (262) \\
\hline 21 & 1.33 & $(-428)$ & 0.80 & (328) & 0.87 & (203) & 0.77 & (334) \\
\hline 22 & 1.18 & $(-264)$ & 0.78 & (366) & 0.85 & $(241)$ & 0.77 & (334) \\
\hline$\geq 23$ & 0.98 & (31) & 0.78 & (366) & 0.85 & $(241)$ & 0.77 & (334) \\
\hline
\end{tabular}

Bron: Bewerking van: Nederlandse bedragen, SZW; Belgische, Ministerie van Tewerkstelling en Arbeid, Belastingdienst; Duitse, Lohnvertrag Eisen-, Metall- und Elektroindustrie, Arbeitsamt Aachen.

Tabel 10. Replacementratio's (R) en absolute afstanden (in guldens) tussen minimumloon en minimumuitkering voor echtparen met 2 kinderen (1992)

\begin{tabular}{|c|c|c|c|c|c|c|c|}
\hline \multirow[t]{3}{*}{ Leeftijd } & \multirow{2}{*}{\multicolumn{2}{|c|}{ Nederland }} & \multicolumn{3}{|c|}{ België } & \multicolumn{2}{|c|}{ BRD } \\
\hline & & & & stand) & (werkl.) & & \\
\hline & $R$ & $f$ & $\mathrm{R}$ & $f$ & $\mathrm{R} \quad f$ & $\mathbf{R}$ & $f$ \\
\hline 20 & 1.45 & $(-572)$ & 1.06 & $(-103)$ & $1.14(-228)$ & 1.11 & $(-149)$ \\
\hline 21 & 1.30 & $(-428)$ & 1.00 & $(-0)$ & $1.07(-126)$ & 1.05 & $(-77)$ \\
\hline 22 & 1.17 & $(-264)$ & 0.98 & (38) & $1.05 \quad(-88)$ & 1.10 & $(-145)$ \\
\hline$\geq 23$ & 0.98 & (31) & 0.98 & (38) & $1.05 \quad(-88)$ & 1.10 & $(-145)$ \\
\hline
\end{tabular}

Bron: Bewerking van: Nederlandse bedragen, SZW; Belgische, Ministerie van Tewerkstelling en Arbeid, Belastingdienst; Duitse, Lohnvertrag Eisen-, Metall- und Elektroindustrie, Arbeitsamt Aachen.

De afstanden tussen de netto minimumuitkeringen en minimumlonen is in Nederland voor een echtpaar zonder kinderen, met een kostwinner in de leeftijdscategorie van 18-22 jaar, negatief (zie noot 16). Datzelfde geldt voor een Belgische kostwinner van 18 jaar met een werkloos-

15. In praktijk zal een replacementratio groter dan één in Nederland niet voorkomen. Wanneer iemand in Nederland na het accepteren van een baan er in inkomen op achter uit gaat ten opzichte van de werkloze situatie, zal aan de betreffende persoon een aanvullende uitkering worden verstrekt. 
heidsuitkering. De replacementratio's voor echtparen met kostwinners zijn in Nederland in alle leeftijdscategorieën groter dan in België en de BRD. Dat betekent dat de afstand tussen het netto minimumloon en de uitkering voor de gegeven leefsituatie in Nederland dus groter is dan voor beide buurlanden.

Tabel 9 laat de afstand tussen minimumloon en uitkering voor een echtpaar met twee kinderen zien. Voor een "jeugdig" echtpaar is uitgegaan van kinderen in de leeftijd van 0-5 jaar; voor een echtpaar met een volwassen kostwinner (23 jaar en ouder) van 6-12 jaar.

Het valt op dat de replacementratio's voor een echtpaar met twee kinderen in alle drie de landen vrij groot zijn. De afstanden tussen de minimumlonen en uitkeringen blijken in veel gevallen negatief. Alleen voor een echtpaar met een kostwinner van 23 jaar en ouder ligt de replacementratio voor de Nederlandse en Belgische bijstand rond de 1. De replacementratio's voor echtparen met een kostwinner jonger dan 23 jaar zijn voor Nederland het grootst in vergelijking met België en de BRD.

Uit het voorgaande kunnen een aantal conclusies worden getrokken. Ten eerste blijken de replacementratio's voor Nederland voor alle drie de leefsituaties groter dan voor België en de Bondsrepubliek Duitstand. Ten tweede toont de vergelijking van de replacementratio's voor de drie leefsituaties dat de replacementratio's voor alleenstaanden kleiner zijn dan voor beide andere leefsituaties. Met uitzondering van de 18 jarige alleenstaande ligt de ratio beneden de waarde 1 en tendeert naar 0.76 voor volwassenen. Vooral voor een echtpaar zonder kinderen blijken de ratio's in Nederland zeer hoog, zo gaat in het geval van een 18 jarige kostwinner, het echtpaar er $f$ 805,-- op achteruit bij deelname aan het arbeidsproces op minimumloonniveau. Het fenomeen van de "poverty trap" ${ }^{16}$ laat zich derhalve in Nederland overduidelijk gelden voor echtparen met en zonder kinderen, waarvan de kostwinner jonger is dan 23 jaar. Het valt op dat vooral jongeren in Nederland te maken hebben met een hoge replacementratio. Voor volwassenen is het verschil tussen de replacementratio's met beide andere landen kleiner.

Bij de vergelijking van het verschil tussen uitkerings- en minimumloonniveaus in de verschillende landen is het uitkeringsniveau voor alleenstaanden van relatief groot belang, omdat het grootste aandeel huishoudens die een minimumloon of een minimumuitkering ontvangen eenpersoonshuishoudens zijn.

Er moeten bij het voorgaande twee opmerkingen gemaakt worden. Ten eerste hebben werklozen in Nederland de verplichting regelmatig te solliciteren. In feite hebben zij dus niet de vrije keuze om zich al dan niet aan te bieden op de arbeidsmarkt afhankelijk van de bestaande loonstructuur. De "job search"theorie gaat er echter van uit dat een sollicitatieplicht niet helpt, er van uitgaand dat individuen zich in de praktijk toch kunnen onttrekken aan het arbeidsproces. De tweede opmerking is dat de cijfers in bovenstaande tabellen (tot en met 10) niet te strikt

16. Verschijnsel waarbij individuen er in besteedbaar inkomen op achteruitgaan na het accepteren van een baan. 
genomen mogen worden; veel bedragen zijn immers op basis van schattingen en generalisatie tot stand gekomen. Denk hierbij onder andere aan het afleiden van de netto minimumloonbedragen via een percentage van het bruto minimumloon voor de BRD. Zoals gezegd is het eveneens mogelijk dat de uitkeringsniveaus voor Nederland en de BRD zijn onderschat door weglating van onder andere huursubsidie voor Nederland en een aantal mogelijke toeslagen voor Duitsland. Desalniettemin geven de tabellen een zo goed mogelijk beeld van de afstanden tussen de netto minimumlonen en netto minimumuitkeringen in Nederland, België en de BRD.

\subsection{Conclusies}

Bij de vergelijking van de minimumloonniveaus tussen Nederland, België en de BRD in hoofdstuk 2 , bleek dat de netto minimumloonbedragen voor jongeren tot 22 jaar in Nederland relatief laag zijn ten opzichte van de twee andere landen. Voor volwassen kostwinners is het minimumloonniveau in Nederland daarentegen relatief hoog voor alleenstaanden en echtparen zonder kinderen. Voor echtparen met twee kinderen waarvan de kostwinner 23 jaar of ouder is, geldt dat het Nederlandse niveau lager is dan in de BRD. De uitkeringsbedragen bleken in Nederland voor alle drie de leefsituaties hoger dan in de BRD. In de vergelijking van Nederland met België kwam naar voren, dat de netto uitkeringsniveaus in Nederland voor echtparen met en zonder kinderen hoger zijn. Voor alleenstaanden geldt in Nederland een hoger uitkeringsbedrag voor volwassenen dan in België.

In dit hoofdstuk zijn vervolgens de afstanden tussen de netto minimumloon- en uitkeringsniveaus onderzocht. Door berekening van zogenaamde replacementratio's zijn de afstanden tussen bijstandsuitkeringen tussen Nederland, België en de BRD vergeleken. Daarmee werd duidelijk dat de replacementratio's in Nederland groter zijn dan in België en de BRD en dat de ratio's kleiner worden naarmate de leeftijd toeneemt. Dat betekent dat de afstanden tussen de minimumloon- en uitkeringsbedragen in Nederland relatief klein zijn.

Op basis van de relatief grote replacementratio's in Nederland kan verwacht worden dat er in vergelijking met België en de BRD meer problemen optreden bij het vervullen van vacatures voor laaggeschoolden en er ook sprake is van een grotere werkloosheid aan de "onderkant" van de arbeidsmarkt. Die problemen ontstaan doordat diegenen waarvan het reserveringsloon boven het minimumloonniveau ligt, zich niet aanbieden voor deze functies. Daarnaast kunnen de relatief grote ratio's voor jongeren in Nederland leiden tot een grotere jeugdwerkloosheid in vergelijking met de twee andere landen. Dit kan het gevolg zijn van de opportuniteitskosten van het werkloos zijn, waardoor het reserveringsloon voor een groot aandeel jongeren boven het huidige minimumloonniveau ligt. Het verschijnsel van de "poverty trap" kan zich voordoen, waarbij werknemers een loon aangeboden krijgen waarmee zij er in inkomen op achteruitgaan vergeleken bij de situatie, waarin zij werkloos zijn. 


\section{DEEL 2}

\section{DE EUREGIONALE ARBEIDSMARKT}

In het tweede deel van deze studie zal worden nagegaan wat de effecten zijn van de bestaande loonstructuren in Nederland, België en de Bondsrepubliek Duitsland op de werking van de arbeidsmarkt. Zoals gezegd zal de analyse zich richten op de arbeidsmarkt in de Euregio Maas-Rijn. Paragraaf 5.1. zal eerst duidelijk maken om welk gebied het gaat en vervolgens de (economische) kenmerken van de Euregio summier beschrijven. Bij de analyse van de vacatureproblematiek wordt doorgaans uitgegaan van gegevens van de arbeidsbureaus en arbeidsvoorzieningsorganisaties. Dit lijken vanzelfsprekend de instellingen te zijn voor de benodigde vacaturegegevens, ware het niet dat de vacatureregistratiegraden in Nederland, België en de Bondsrepubliek Duitsland slechts tussen de 20 en $45 \%$ liggen. De mogelijke consequenties daarvan zullen in paragraaf 5.2 uiteen gezet worden.

\subsection{De Euregio Maas-Rijn}

Het gebied waarvoor een analyse van de vacature- en werkloosheidsproblemen plaatsvindt omvat grotendeels de officiële Euregio Maas-Rijn. Deze Euregio wordt gevormd door het grensgebied van Nederlands en Belgisch Limburg, het Belgische Luik en het Gewest Aken en vormt een "grensoverschrijdende werkgemeenschap van de gouverneurs van deze provincies en van de "Regierungspräsident" van Keulen en de politieke vertegenwoordigers", opgericht in 1976 (Goethals ,1990). Het doel dat met de oprichting werd nagestreefd is de "saamhorigheid van de bewoners en de samenwerking op het terrein van bestuur, economie, cultuur, onderwijs en infrastructuur te bevorderen" en op deze wijze de positie van de bevolking in het "hart van Europa" te verbeteren (Goethals, 1992).

Het hier bestudeerde gebied omvat overigens niet de gehele Euregio Maas-Rijn; de Belgische provincie Luik en een gedeelte van het Duitse "Arbeitsamtbezirk" Brühl worden buiten beschouwing gelaten. De overgebleven regio's zijn de Belgische provincie Limburg, het "Arbeitsamtbezirk" Aken in de BRD en de regio Zuid-Limburg in Nederland. Zuid-Limburg is daarbij weer te onderscheiden in drie deelgebieden: de Westelijke en Oostelijke Mijnstreek en het Gewest Maastricht.

Een argument voor het weglaten van het gedeelte (Euskirchen) dat in het "Arbeitamtbezirk" Brühl ligt, is dat in de arbeidsbureaucijfers van Duitsland de gegevens voor Euskirchen dat in het "bezirk" Brühl ligt ontbreken. Het betreft hier een natuurgebied dat in de Eifel ligt met slechts minder dan $4 \%$ van de bevolking in het Duitse gedeelte van de Euregio.

De provincie Luik is eveneens buiten beschouwing gelaten, vanwege het ontbreken van vacaturegegevens. Alhoewel het hierbij om een groot gebied gaat met veel inwoners is er sprake van weinig wisselwerking op de arbeidsmarkt als gevolg van de bestaande taalbarrière in 
België. Wanneer in het vervolg over de Euregio gesproken wordt, wordt het hierbinnen afgebakende gebied bedoeld en niet de officiële grensoverschrijdende werkgemeenschap. Bovendien zullen in bepaalde gevallen cijfers voor de gehele Nederlandse provincie Limburg worden weergegeven in plaats van alleen de data voor de regio Zuid-Limburg. De reden hiervan is het ontbreken van cijfers die uitgesplitst kunnen worden naar dit laatste regioniveau.

Tabel 11. Enkele kerngetallen van de deelgebieden in de Euregio Maas-Rijn

\begin{tabular}{|c|c|c|c|c|}
\hline & & $\begin{array}{l}\text { Nederlands } \\
\text { Limburg }\end{array}$ & $\begin{array}{l}\text { Belgisch } \\
\text { Limburg }\end{array}$ & $\begin{array}{l}\text { Gewest } \\
\text { Aken }\end{array}$ \\
\hline \multirow{3}{*}{\multicolumn{2}{|c|}{$\begin{array}{l}\text { bevolking per } 1-1-1991 \text { ( } \times 1000) \\
\text { procentuele bevolkingsgroei per jaar (1990-2000) } \\
\text { bevolkingsdichtheid per km (1990) }\end{array}$}} & $451 *$ & $741 * *$ & $736 *$ \\
\hline & & 0.2 & 0.3 & -0.1 \\
\hline & & 500 & 308 & 329 \\
\hline \multirow{2}{*}{\multicolumn{2}{|c|}{$\begin{array}{l}\text { potentiële beroepsbevolking }(\times 1000) \\
\% \text { groei per jaar }(1990-95)\end{array}$}} & $287^{*}$ & $319 * *$ & $319 * *$ \\
\hline & & 0.7 & 0.0 & - \\
\hline \multicolumn{2}{|c|}{$\begin{array}{l}\text { procentuele groei werkgelegenheid in } \\
\text { dienstverband } 1985-1989\end{array}$} & 4.1 & 3.0 & 1.4 \\
\hline \multicolumn{2}{|c|}{$\begin{array}{l}\text { werkloosheid }(\%) \\
\text { bruto regionaal produkt }\end{array}$} & 7.7\# & 7.9\# & $9.0^{* * *}$ \\
\hline \multicolumn{2}{|c|}{ per inwoner '88 (EUR $=100)$} & 90 & 93 & 84 \\
\hline \multicolumn{5}{|c|}{$\quad=$ onbekend } \\
\hline \multicolumn{5}{|c|}{ * $\quad$ CBS, Enquête beroepsbevolking 1991; cijfer geldt voor het RBA gebied Zuid-Limburg (NL). } \\
\hline & $\begin{array}{l}\text { ETIL (1990) Vraag en aanbod op de arb } \\
1990 \text { voor België; } 1987 \text { voor Gewest Ake }\end{array}$ & narkt in inter & al perspect & 11, cijfers uit \\
\hline *** & Arbeitsamt Aachen (1992) Presseinformat & & & \\
\hline $\begin{array}{l}\# \\
\text { Bron: }\end{array}$ & $\begin{array}{l}\text { EUROSTAT; Nederlandse cijfers van } 1990 \\
\text { ETIL L-SEV'91, p. } 39\end{array}$ & gische cijfers & 91. & \\
\hline
\end{tabular}

Tabel 11 laat zien dat de bevolkingsomvang in de Belgische en Duitse deelregio van vergelijkbare grootte is en dat het bevolkingsaantal in het Nederlandse gedeelte daarvan ongeveer de helft bedraagt. Alleen voor het Gewest Aken wordt een daling van de bevolkingsomvang verwacht in de jaren 1990-2000. De bevolkingsdichtheid is in het Nederlandse deel van de Euregio aanmerkelijk groter dan in de beide andere delen. In tegenstelling tot de bevolkingsgrootte is de potentiële beroepsbevolking in alle drie de deelregio's van de Euregio van vergelijkbare grootte. Hoewel voor het Nederlandse deel in de jaren 1990-1995 een groei van de potentiële beroepsbevolking van 0.7 wordt verwacht, wordt in de jaren daarna een forse daling verwacht door afname van het aantal jongeren (ETIL, 1990). Hetzelfde geldt voor de twee andere deelregio's, waar op langere termijn eveneens een afnemende groei van de potentiële beroepsbevolking wordt verwacht als gevolg van demografische factoren.

In alle drie de deelgebieden is mijnbouw in het verleden van groot belang geweest. In Nederlands Limburg is in 1974 de laatste mijn gesloten, in Belgisch Limburg zijn er in 1987 en 1988 drie mijnen gesloten en is ook de sluiting van de laatste twee mijnen gepland. In het 
Gewest Aken zal eind 1992 de laatste mijn worden gesloten. In de jaren 1960-1984 zijn in de Euregio Maas-Rijn als gevolg van de mijnsluitingen circa 100.000 arbeidsplaatsen verloren gegaan. De dienstensector heeft in alle drie de deelgebieden het meest bijgedragen aan de werkgelegenheidsgroei. Een werkgelegenheidsgroei die overigens in de beide Limburgen het grootst is geweest: Nederlands Limburg 2,3\%, Belgisch Limburg 2,6\%, Gewest Aken 1,3\% (ETIL 1989). De werkloosheidscijfers in tabel 11 zijn niet geharmoniseerd en kunnen derhalve niet onderling vergeleken worden. In hoofdstuk 7 zal uitgebreid worden ingegaan op de werkloosheid binnen de Euregio, waarbij deze voor de drie deelregio's vergeleken worden.

\subsection{Beleidsvoering arbeidsbureaus}

De Arbeidsvoorziening Zuid-Limburg richt zich met haar beleid op de gehele arbeidsmarkt. Binnen dit beleid wordt de zogenaamde "doelgroepenbenadering" gevolgd. Doelgroepen zijn: (etnische) minderheden, jongeren, vrouwen, langdurig werklozen en gedeeltelijk arbeidsongeschikten. Daarnaast zal in de toekomst meer aandacht worden besteed aan hoger opgeleiden, omdat HBO'ers en universitair geschoolden een steeds groter aandeel in het werkzoekendenbestand in gaan nemen (Arbeidsvoorziening Zuid-Limburg, 1992).

Wat de vraagkant van de arbeidsmarkt betreft worden intensieve bedrijfscontacten onderhouden en is een PR-commissie ingesteld om de werkgevers bekend te maken met de regels en activiteiten van het RBA en de arbeidsbureaus. Op deze wijze wordt getracht werkgevers te stimuleren meer vacatures aan te melden. Op dit moment komen werkgevers vaak pas naar het arbeidsbureau nadat werving via een ander kanaal mislukt is.

De arbeidsvoorzieningsorganisatie wil op deze wijze dus het marktbereik ${ }^{17}$ en het marktaandeel $^{18}$ van de arbeidsbureaus vergroten (Arbeidsvoorziening Zuid-Limburg 1992). Vanuit een arbeidsbureau in de regio wordt echter duidelijk dat het marktaandeel niet, zoals in het verleden, zonder meer vergroot moet worden, maar dat er bij het binnenhalen van vacatures wel een reële kans op vervulling moet bestaan. Op nationaal niveau lag het marktbereik in 1988 op $37 \%$ en in 1989 op $43 \%$. Voor de regio Zuid-Limburg bestaan geen schattingen voor het marktbereik, omdat de totale vraag voor de regio (nog) niet bekend is. In 1992 zal dit cijfer aan de hand van een dan ontworpen model wel geschat kunnen worden (uitspraak RBA Zuid- Limburg). Het marktaandeel, gedefinieerd als het aandeel van de door de arbeidsbureaus vervulde vacatures in het totale vacaturebestand, bedroegen in 1988 en ' 89 in Nederland respectievelijk 20 en 23\% (Directoraat Generaal voor de Arbeidsvoorziening 1988, 1989). Voor de regio ZuidLimburg wordt het marktaandeel geschat op $21 \%$. Er moet echter niet teveel betekenis aan dit cijfer gehecht worden vanwege de wijze waarop dit getal tot stand is gekomen (uitspraak RBA

17. "Marktbereik (ook wel: registratiegraad) = aandeel van de bij de arbeidsbureaus aangemelde vacatures ten opzichte van het totale vacaturebestand (in Nederland)" (Jaarverslag '88 Arbeidsvoorziening, p.12).

18. "Marktaandeel $=$ aandeel van de door de arbeidsbureaus vervulde vacatures in het totale vacaturebestand (in Nederland)" (Jaarverslag '88 Arbeidsvoorziening, p. 12). 
Zuid-Limburg). Verder wordt aan de hand van intensief beleid in de regio, de problemen aangepakt in het midden- en kleinbedrijf (MKB), de gezondheidszorg, de bouw en de horeca ${ }^{19}$. Onder dit beleid valt het scholen van het arbeidsaanbod en het gericht voeren van een acquisitiebeleid ten aanzien van vacatures. In het MKB worden niet speciaal vacatures geworven, omdat daar minder problemen zijn met de werving van vacatures dan bij het grootbedrijf.

De Vlaamse Dienst voor de Arbeidsbemiddeling en Beroepsopleiding (VDAB) in België voert eveneens een doelgroepenbeleid, gericht op vrouwen, migranten, gehandicapten en langdurig werklozen (regeeraccoord van de Vlaamse Regering op het gebied van de werkgelegenheid, 1992). Werkzoekenden die langer dan zes maanden werkloos zijn, zullen, eventueel via scholing, bemiddeld worden naar bestaande knelpuntberoepen als: lasser, verpleegkundige, mecaniciën en monteur. Over het marktaandeel en marktbereik van de arbeidsbureaus in België is weinig bekend. Wel bestaat er een registratieplicht voor vacatures. Alle ontstane vacatures moeten binnen drie dagen na externe werving bij het arbeidsbureau worden geregistreerd (OESO, 1991). De studiedienst van het VDAB heeft in 1990 enkele enquête-onderzoeken verricht. Daarin wordt het marktbereik op het gebied van de vacatureregistratie op zo'n $45 \%$ geschat (Ministerie van de Vlaamse Gemeenschap, Nota aan het beheerscomité, 1990.) Een medewerker van de studiedienst vermoedt echter dat dit cijfer overschat zal zijn. Er vindt ondanks de bestaande registratieplicht nauwelijks echte werving van vacatures bij werkgevers plaats $^{20}$.

In de BRD vinden regelmatig bedrijfsbezoeken plaats ten behoeve van de werving van vacatures. Werkgevers en werkzoekenden worden beide als klanten beschouwd en er wordt getracht zoveel mogelijk aan hun wensen te voldoen. Dat wordt gedaan met een duidelijke marketingstrategie, een gerichte acquisitie, scholing van het arbeidsaanbod en kosteloze bemiddeling. Er geldt geen registratieplicht voor ontstane vacatures. De registratiegraad van vacatures bij de arbeidsbureaus wordt geschat op zo'n 20 tot $25 \%$, met een gemiddelde vervullingsquote van ongeveer $75 \%$.

In de analyse worden openstaande en moeilijk vervulbare vacatures afkomstig van de arbeidsbureaus in Nederland, België en de BRD vergeleken. Het is van belang na te gaan hoe representatief deze cijfers zullen zijn voor de betreffende deelarbeidsmarkten.

Hierboven werd duidelijk dat de registratiegraden van het aantal vacatures in de drie landen relatief laag zijn: $21 \%$ in Zuid-Limburg (NL), tussen de 30 en $45 \%$ in België en 20 tot $25 \%$ in Duitsland.

19. In de Westelijke Mijnstreek richt het "speerpuntenbeleid" zich ook de metaal.

20. Op basis van een officieus onderzoek wordt de Vlaamse vacatureregistratiegraad op zo'n $30 \%$ geschat. 


\section{VACATUREPROBLEMATIEK}

In dit hoofdstuk worden onder andere het aantal openstaande vacatures, de vacatureduren en de hiermee samenhangend moeilijk vervulbare vacatures naar beroepsgroep en opleidingsniveau in de Euregio Maas-Rijn ${ }^{21}$ behandeld. Er wordt onderzocht of er aanwijzigingen kunnen worden gevonden voor het bestaan van een relatie tussen de enerzijds relatief kleine afstand tussen minimumloon en uitkering in Nederland en anderzijds het groot aantal openstaande en moeilijk vervulbare vacatures op de arbeidsmarkt. De vacatures waar het in dit geval om gaat, zullen zich naar verwachting op de laagste onderwijsniveaus bevinden, omdat juist deze werknemers met minimumbeloningen te maken hebben. Ondanks het ontbreken van vergelijkbaar materiaal is toch getracht een zo goed mogelijke vergelijking tussen de drie deelgebieden te maken.

In hoofdstuk 5 bleek dat de registratiegraden van het aantal vacatures betrekkelijk laag zijn $21 \%$ in Zuid-Limburg (NL), tussen de 30 en $45 \%$ in België en zo'n 20 tot 25\% in de BRD. Daarbij kan bovendien aangenomen worden dat de arbeidsbureaus meestal niet het eerste wervingskanaal voor de werkgevers zijn, wat wellicht tot gevolg heeft, dat de wat moeilijker vervulbare vacatures bij de bureaus terecht komen. Daarnaast hebben de arbeidsbureaus voor bepaalde marktsegmenten een groter marktaandeel dan voor andere ${ }^{22}$.

Paragraaf 6.1 zal eerst ingaan op de openstaande vraag naar beroepsgroep en opleidingsniveau, waarna in paragraaf 6.2. de moeilijk vervulbare vacatures naar beroepsgroep en opleidingsniveau worden behandeld. In paragraaf 6.3. wordt naar aanleiding van de conclusies van de voorgaande twee paragrafen een relatie met de Nederlandse loonstructuur gelegd.

\subsection{Openstaande vacatures}

Vacatures naar beroepsgroep

Het is moeilijk om tot een goede vergelijking van de openstaande vraag naar beroepsgroep te komen voor Nederlands en Belgisch Limburg en het Gewest Aken, omdat deze gegevens op verschillende indelingen zijn gebaseerd. De Nederlandse indeling ${ }^{23}$ bestaat uit 17 categorieën, tegenover een indeling in 27 naar beroepsgroepen voor arbeiders en 27 beroepsgroepen "bedienden" in België en 41 beroepscategorieën in de BRD. Desondanks kan getracht worden een algemeen beeld af te leiden. Dat beeld blijkt voor de drie deelmarkten redelijk vergelijkbaar. In het (Euregionale gedeelte van het) Nederlandse Limburg bevinden zich relatief veel openstaande vacatures in de volgende beroepsgroepen: metaal, bouw B\&U, handel en de algemene diensten (ETIL, 1990). Voor Belgisch Limburg gaat het voor de categorie arbeiders

21. Het gaat hier om het gebied omschreven in hoofdstuk 5 .

22. Voor de opleidingsniveaus LBO, MAVO beschikken de Nederlandse arbeidsbureaus over een relatief groot marktaandeel.

23. De gegevens zijn afkomstig van het ETIL. 
vooral om de vacatures: metaalbewerker, werknemer verkeer en bouwarbeider; voor de categorie bedienden: verkoper, andere bureaubedienden en technicus ${ }^{24}$. De vier beroepsgroepen waarvoor in het Gewest Aken een grote openstaande vraag bestaan, zijn (Statistik Arbeitsamt Aachen, 1992): "Organisations-, Verwaltungs- und Büroberufe", "Schlosser, Mechaniker und zugehörige Berufe", "Warenkaufleute" en "Reinigungsberufe". Tabel 12 geeft een overzicht van beroepsgroepen waarvoor in de drie deelregio's sprake is van een grote openstaande vraag.

Tabel 12 Beroepsgroepen met een relatief groot aantal openstaande vacatures

$\begin{array}{ccc}\begin{array}{c}\text { Zuid-Limburg } \\ (1990)\end{array} & \text { Belgisch Limburg } & \text { Gewest Aken } \\ & (1991) & (1992)\end{array}$

$\begin{array}{lll}\text { metaal } & \text { metaalbewerker } & \text { Org., Verwaltungs u Büroberuf* } \\ \text { bouw B\&U } & \text { verkoper } & \text { Schlosser, Mechan.u zug.Berufe } \\ \text { handel } & \text { andere bureaubedienden } & \text { Warenkaufleute } \\ \text { algemene diensten } & \text { technicus } & \text { Reinigungsberufe } \\ \text { horeca } & \text { werknemer verkeer } & \\ \text { kantoor } & \text { bouwarbeider } & \end{array}$

Bron: ETIL (1990) Openstaande vraag naar herstructureringsgebied; VDAB (1991) Statistieken over de werkaanbiedingen uit het gewoon economisch gebied; Statistik Arbeitsamt Aachen (1992).

* Organisations-, Verwaltungs- und Büroberuf.

* * Schlosser, Mechaniker und zugehörige Berufe.

In alle drie de deelarbeidsmarkten van de Euregio Maas-Rijn bestaat een grote openstaande vraag voor beroepsgroepen die vergelijkbaar zijn met de Nederlandse beroepscategorieën metaal, handel en algemene diensten. Bij de laastste categorie is er voor wat Nederland betreft van uitgegaan dat het hier vooral om administratieve diensten gaat. De beroepsgroep bouw komt alleen in Nederland en in België naar voren als een tekortcategorie. De aandelen van de openstaande vacatures voor bovenstaande beroepsgroepen zijn terug te vinden in Bijlage $B$ in de tabellen I, II en III.

In tabel 13 is getracht de beroepen in Nederland, België en de BRD in zes categorieën in te delen om de openstaande vraag voor vergelijkbare beroepsgroepen te beschouwen. Daarbij is de indeling gebaseerd op bedrijfssectoren. Doordat de beroepsgroepen als het ware zijn geharmoniseerd kunnen ze voor de verschillende landen vergeleken worden.

Het totale aantal openstaande vacatures per 1000 bezette arbeidsplaatsen is voor de Belgische deelregio duidelijk lager dan voor de Nederlandse en Duitse deelregio's. Dit terwijl de registratiegraad van vacatures bij de arbeidsbureaus in België, zoals gezegd, tevens groter is dan in beide

24. VDAB (1991) Statistieken over de werkaanbiedingen uit het gewoon economisch circuit. 
andere landen. De tabel laat zien dat in de drie regio's de aandelen van de verschillende beroepsgroepen in het totale aantal openstaande vacatures uiteen lopen. Zo is het aantal openstaande vacatures in de Belgische nijverheid relatief groter dan in Nederland en de BRD. In de twee laatst genoemde landen is daarentegen het aantal vacatures voor het dienstenpersoneel juist groter.

Tabel 13 Absolute en relatieve openstaande vraag naar beroepsgroepen in 1989

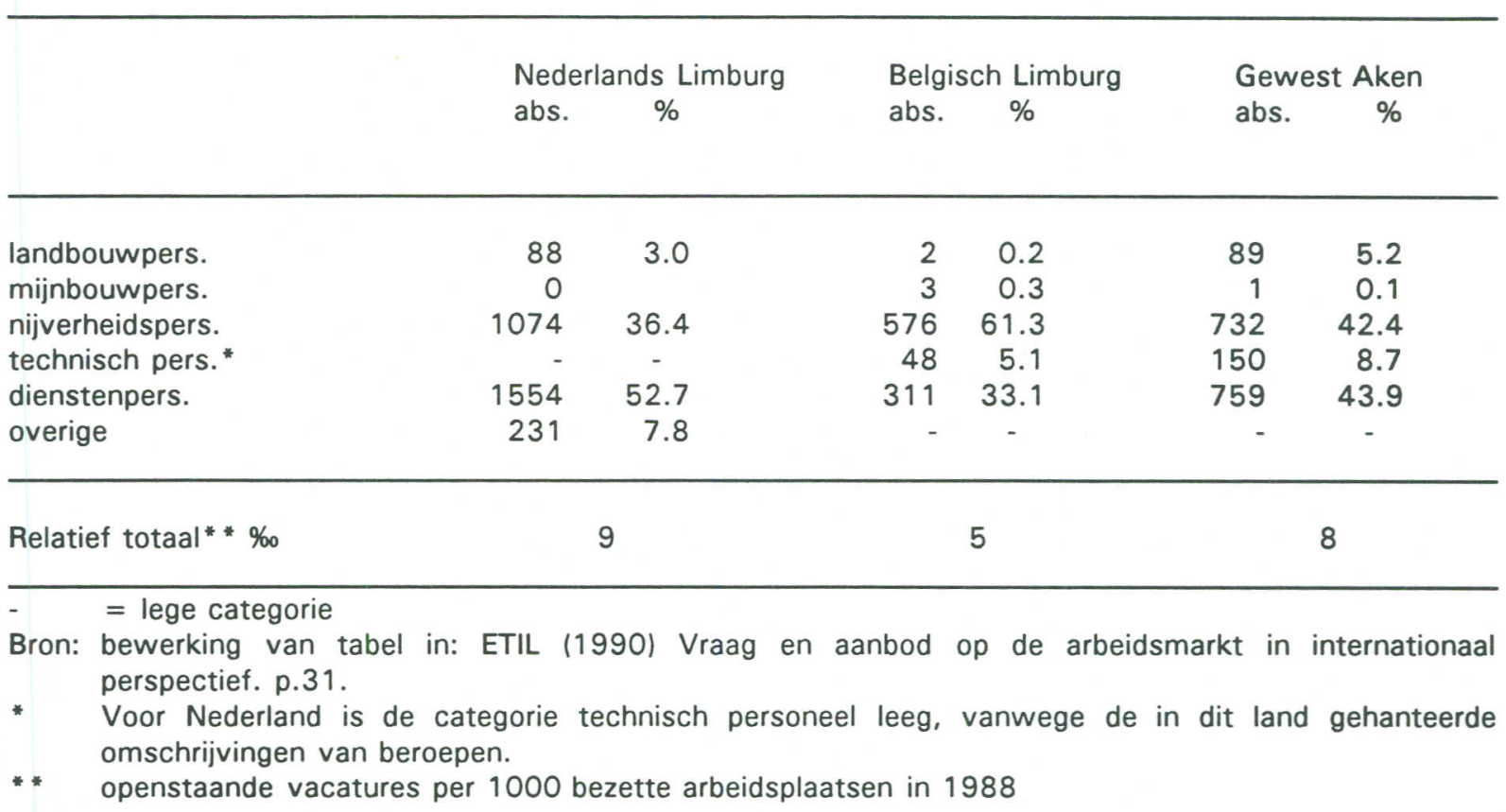

Wanneer het relatieve aantal openstaande vacatures naar beroepsgroep wordt gerelateerd aan de werkgelegenheid, wordt het relatieve belang van de openstaande vraag duidelijk. Tabel I in bijlage $\mathrm{C}$ geeft de werkgelegenheid weer in de vorm van het aantal banen naar bedrijfssectoren. Daaruit blijkt dat de werkgelegenheid in de nijverheid ${ }^{25}$ in het deelgebied van de BRD groter is dan in het Nederlandse en de Belgische gedeelte. Hiermee lijkt in ieder geval het relatief grote aandeel van deze bedrijfssector in de openstaande vraag in het Duitse gedeelte ten opzichte van Nederlands Limburg verklaard. Dit geldt echter niet voor het Belgische deel, waar het aandeel van de nijverheid in de werkgelegenheid min of meer vergelijkbaar is met het Nederlandse niveau. Het grote aantal openstaande vacatures in de Belgische nijverheid blijkt derhalve niet uitsluitend met het aandeel in de werkgelegenheid samen te hangen.

Wanneer de beroepsgroep diensten in tabel 13 ongeveer gelijk wordt gesteld aan de sectoren handel en horeca, verkeer en vervoer en overige diensten in tabel I van bijlage C, blijkt dat het werkgelegenheidsniveau in deze sector in Nederland het hoogste is, gevolgd door respectievelijk het Belgische en het Duitse deel. Daaruit blijkt dat de kleine openstaande vraag voor de

25. Nijverheid + bouwnijverheid in tabel 1 , bijlage $C$. 
Belgische diensten ten opzichte van de twee andere gebieden niet louter verklaard kan worden met het werkgelegenheidsaandeel. In het algemeen blijkt dus dat het aantal openstaande vacatures in Belgisch Limburg geringer is dan in de andere delen van de Euregio', in het Belgische deel is sprake van een opvallend groot aantal openstaande vacatures in de nijverheid en een juist klein aantal in de dienstensector, die niet verklaard kunnen worden door het aandeel in de werkgelegenheid.

\section{Vacatures naar opleidingsniveau}

Gegevens over de openstaande vraag naar opleidingsniveau voor Zuid-Limburg (NL) ontbreken. Wel zijn er (stroom)cijfers voor de instroom van vacatures naar opleidingsniveau voor Maastricht bekend ${ }^{26}$. Hieruit kan een indicatie van de opleidingsniveaus waarvoor veel openstaande vacatures bestaan afgeleid worden. Dan blijkt dat de grootste aandelen van de "vacatureinstroom" zowel in absolute als in relatieve zin, geen bepaalde opleiding en LBO, MAVO vereisen ${ }^{27}$. Voor de openstaande vraag naar opleidingsniveau in Belgisch Limburg bestaan er wel bestandgegevens, welke bovendien betrekking hebben op de gehele provincie (VDAB, 1991). Omwille van de vergelijkbaarheid geeft tabel $V$ in bijlage $B$ naast bestandgegevens toch ook stroomcijfers. Het beeld dat daaruit naar voren komt laat zien dat voor het grootste deel van de openstaande vraag slechts lager onderwijs vereist is. Daarnaast blijkt er een grote openstaande vraag te bestaan met lager secundair technisch onderwijs als kwalificatievereiste. Voor het Gewest Aken is uitsluitend sprake van bestandcijfers voor het aantal openstaande vacatures naar opleidingsniveau (Arbeitsamt Aachen sept. 1991). De vereisten voor het grootste aandeel in de openstaande vraag zijn geen opleiding en Ausbildung/Lehre ${ }^{28}$. Kortom, ook voor wat betreft het aantal openstaande vacatures naar opleidingsniveau blijkt het beeld voor de drie deelmarkten in de Euregio vergelijkbaar. Dit wordt nog eens weergegeven door tabel 14. Deze geeft de aandelen van de openstaande vraag naar opleidingsniveau voor vier opleidingscategorieën weer. In bijlage B (tabel IV t/m VI) worden de openstaande vacatures naar opleidingsniveau uitvoeriger weergegeven.

Tabel 15 laat zien hoe de vier categorieën opleidingsniveaus voor de drie beschouwde landen zijn opgebouwd. Alvorens op de gegevens van tabel 14 en 15 in te gaan moet worden opgemerkt dat de weergegeven opleidingscategorieën niet horizontaal vergeleken kunnen worden. De tabellen laten zien dat het grootste aandeel van de openstaande vacatures in de Nederlandse en Belgische deelregio het laagste opleidingsniveau als kwalificatievereiste stellen. In deze gebieden bestaat er derhalve dus een grote openstaande vraag naar ongeschoolde en laaggeschoolde arbeid. Overigens is de procentuele instroom van het aantal openstaande vacatures voor ongeschoolden in het Nederlandse gedeelte van de Euregio Maas-Rijn het

26. Gegevens CBA (1991) LAVADA bestand.

27. Arbeidsvoorziening heeft een relatief groot marktaandeel op dit marktsegment. Dit doet echter niets af aan de conclusies.

28. Beide opleidingen vallen onder het beroepsonderwijs. 
grootst. In het Gewest Aken blijkt de meerderheid van de openstaande vraag het tweede onderwijsniveau te vereisen. Wanneer naast de gegeven twee tabellen de bestandcijfers voor de openstaande vraag naar opleidingsniveau in de tabellen IV tot en met VI in bijlage B bekeken worden, blijkt het beeld voor de drie deelgebieden redelijk vergelijkbaar. Zo stelt de meerderheid van de openstaande vacatures de laagste twee kwalificatieniveaus (1 en 2) als vereiste.

Tabel 14 Het relatieve aantal openstaande vacatures naar opleidingsniveau $(1991)^{29}$

\begin{tabular}{llll}
\hline opleidingsniveau & $\begin{array}{l}\text { Gewest } \\
\text { Maastricht } \\
\% \text { instroom }\end{array}$ & $\begin{array}{l}\text { Belgisch } \\
\text { Limburg } \\
\% \text { instroom }\end{array}$ & $\begin{array}{l}\text { Gewest } \\
\text { Aken } \\
\% \text { bestand }\end{array}$ \\
\hline 1 & 54 & 43 & 31 \\
2 & 24 & 20 & 54 \\
3 & 16 & 20 & 2 \\
4 & 5 & 16 & 12 \\
& & & Aachen \\
\hline Bron: CBA (1991) LAVADA-bestand; VDAB (1991) Statistieken over de werkaanbiedingen uit het gewoon \\
(sept. \\
economisch circuit, in: \\
Sonderuntersuchung.
\end{tabular}

Tabel 15 Verklaring van de opleidingsniveaus $1 \mathrm{t} / \mathrm{m} 4$ *

\begin{tabular}{|c|c|c|c|}
\hline opleidingsniveau & Nederland & België & BRD \\
\hline 1 & $\begin{array}{l}\text { ongeschoold } \\
\text { basionderwijs }\end{array}$ & lager onderwijs & ongeschoold \\
\hline 2 & $\begin{array}{l}\text { MAVO } \\
\text { LBO }\end{array}$ & $\begin{array}{l}\text { lager sec.alg.vormend } \\
\text { lager sec.technisch } \\
\text { lager sec.beroeps }\end{array}$ & $\begin{array}{l}\text { Ausbildung } \\
\text { Lehre }\end{array}$ \\
\hline 3 & $\begin{array}{l}\text { HAVO } \\
\text { VWO } \\
\text { MBO }\end{array}$ & $\begin{array}{l}\text { hoger sec.alg.vormend } \\
\text { hoger sec.technisch } \\
\text { hoger sec.beroeps/aanv. }\end{array}$ & $\begin{array}{l}\text { BFS } \\
\text { Fachschule }\end{array}$ \\
\hline 4 & $\begin{array}{l}\text { HBO } \\
\text { WO }\end{array}$ & $\begin{array}{l}\text { hoger onderwijs (HOBU) } \\
\text { Fachh.schule }\end{array}$ & Hochschule \\
\hline
\end{tabular}

* In de tabellen IV, V en VI, bijlage B, worden de gegevens verder verduidelijkt.

29. Let op dat stroom-en bestandcijfers niet horizontaal vergeleken mogen worden. 


\subsection{Moeilijk vervulbare vacatures}

\section{Vacatures naar beroepsgroep}

Er bestaan verschillende definities voor moeilijk vervulbare vacatures. De arbeidsbureaus beschouwen vacatures die lang openstaan als moeilijk vervulbaar. Daarbij wordt in Nederland een vacatureduur van minimaal drie maanden en in België twee maanden als maatstaf gehanteerd. Door de Duitse arbeidsbureaus worden vacatures waarbij zich problemen voordoen als moeilijk vervulbaar gezien. In praktijk blijken dat met name vacatures te zijn waarvoor een grote openstaande vraag bestaat. Gegevens omtrent de vacatureduren naar beroepsgroep zijn daarmee niet bekend. Wel verzamelen de Duitse arbeidsbureaus gegevens over de vacatureduur naar "soort" beroep. Deze zullen dan ook in volgende gedeelte beschouwd worden.

In het Nederlandse deel van de Euregio staat ongeveer $27 \%$ van het aantal vacatures langdurig open (RBA, 1991). Door cijfers over moeilijk vervulbare vacatures voor de Westelijke en Oostelijke Mijnstreek als representatief voor geheel Zuid-Limburg te veronderstellen, wordt duidelijk om welke vacatures (naar beroepsgroep) het gaat. In de Westelijke Mijnstreek speelt naast de bouw (33\%), de beroepsgroep metaal (24\%) een belangrijke rol in het aandeel langdurig openstaande vacatures. Voor de Oostelijke mijnstreek zijn er naast een groot aantal moeilijk vervulbare vacatures in de bouw ook veel moeilijk vervulbare vacatures in de categorie horeca en overige dienstverlening.

Een andere wijze om moeilijk vervulbare vacatures te benaderen naast de vacatureduur, is het in beeld brengen van de vervullingsquote van het arbeidsbureau. Deze vervullingsquotes zijn in het arbeidsbureaugewest Maastricht laag voor de beroepsgroepen bouw en industrie. Een derde subjectieve methode om moeilijk vervulbare vacatures te registreren is door werkgevers er naar te vragen. Deze werkwijze is gehanteerd in de CBS vacatureenquête ${ }^{30}$. Uit deze enquête komt naar voren dat de helft van het aantal vacatures moeilijk vervulbaar is. Dat komt overeen met het aantal vacatures met een zoekperiode langer dan drie maanden ${ }^{31}$. De percentages volgens de CBS enquête (1990) liggen overigens wel hoger dan volgens de gegevens van de arbeidsbureaus en het RBA Zuid-Limburg.

Bij de moeilijk vervulbare vacatures voor de Belgische regio, valt op dat het om dezelfde beroepsgroepen gaat als waarvoor veel openstaande vacatures bestaan. De beroepsgroepen waarvoor de openstaande vraag groot is, blijken dus ook als moeilijk vervulbaar te gelden. Het gaat daarbij om de beroepsgroepen: metaalbewerker, electriciën, bouwarbeider, verkoper, andere bureaubedienden en technicus.

Zoals eerder werd aangegeven wordt in de BRD geen eenduidige definitie voor moeilijk

30. De gegevens van de CBS vacatureenquête (1990) zijn in tabel VIII, bijlage B weergegeven.

31. Deze is namelijk $3.2-(0.7+0.8)=1.7$. 
vervulbare vacatures gehanteerd. De beroepen waarvoor sprake is van een grote openstaande vraag worden tevens gezien als de beroepen met vacatures die moeilijk te vervullen zijn. Het gaat in het "Arbeitsamtbezirk" Aken om beroepsgroepen in de techniek: metaal, bouw en elektrotechniek; in de administratieve sector en de detailhandel. Vooral in de eerstgenoemde beroepsgroep schijnen de arbeidsomstandigheden bepalend te zijn. Voor de tweede beroepsgroep geldt een onvoldoende gekwalificeerd aanbod en (te) hoge eisen aan de vraagzijde van de arbeidsmarkt. In tegenstelling tot de Nederlandse en Belgische cijfers beschikken de Duitse arbeidsbureaus alleen over vacatureduren naar "soort" beroep. Daarin komt naar voren dat vacatureduren van drie tot zes maanden en langer dan zes maanden, vooral voorkomen bij "Facharbeiter" en "nicht Facharbeiter" ${ }^{32}$.

Tabel 16 geeft een overzicht van het aandeel moeilijk vervulbare vacatures naar beroepsgroep en naar soort beroep waar het de BRD betreft. De percentages zijn terug te vinden in de tabellen VII, VIII en IX in bijlage B, deze tabellen geven het aandeel moeilijk vervulbare vacatures per deelmarkt uitgebreid weer.

Tabel 16 Moeilijk vervulbare vacatures naar beroepscategorie (1991)

Zuid-Limburg (NL) Belgisch Limburg Gewen

\begin{tabular}{lll}
\hline bouw & metaalbewerker & Facharbeiter/qualifiziert \\
metaal & verkoper & nicht Facharbeiter \\
horeca & elektriciën & \\
overige dienstverl. & andere bureaubed. & \\
pers.alg.dienst & bouwarbeider & \\
& technicus & \\
\end{tabular}

In de Euregio Maas-Rijn blijken in de beroepsgroepen bouw, metaal en techniek ${ }^{33}$ veel moeilijk vervulbare vacatures voor te komen. Verder blijken beroepsgroepen waarvoor een grote openstaande vraag bestaat, dezelfde beroepsgroepen als waarvoor veel moeilijk vervulbare vacatures bestaan.

Vacatures naar opleidingsniveau

De meerderheid van aantal moeilijk vervulbare vacatures in de Nederlandse en Belgische deelregio blijken, evenals voor het grootste aandeel van de openstaande vraag, de onderste twee opleidingsniveaus als kwalificatievereiste te stellen. In het Nederlandse en Belgische gedeelte van de Euregio Maas-Rijn blijkt dat aandeel moeilijk vervulbare vacatures, evenals bij de

32. Niet- of laaggeschoolde arbeider.

33. Vormt in Nederland geen aparte beroepsgroep, maar valt onder de genoemde beroepsgroepen, in dit geval onder metaal en bouw. 
totale openstaande vraag, de onderste twee opleidingsniveaus als kwalificatievereisten worden gesteld. In het Nederlandse geval zijn dat: geen kwalificatievereisten en LBO, MAVO; en in het Belgische: lager onderwijs en secundair (technisch) onderwijs. Overigens blijken de vervullingsquotes van vacatures naar opleidingsniveau, genoemd in tabel $\mathrm{V}$, bijlage $\mathrm{B}$, opvallend groter dan die voor het Nederlandse deel ${ }^{34}$. Voor het Gewest Aken zijn slechts vacatureduren naar soort beroep bekeken in verband met het ontbreken van verdere gegevens. Deze zijn in het bovenstaande bij de analyse van het aandeel moeilijk vervulbare vacatures naar beroepsgroep al genoemd. Duidelijk werd dat knelpunten zich vooral voordoen in de vacaturevervulling voor vakarbeiders met een zekere kwalificatie. Daarmee lijken de belangrijkste problemen zich in het Duitse deel dus niet voor te doen op het ongeschoolde niveau. Tabel 17 geeft een overzicht van de moeilijk vervulbare vacatures naar opleidingsniveau voor de Euregio Maas-Rijn.

Tabel 17 Twee belangrijkste categorieën moeilijk vervulbare vacatures naar opleidingsniveau/soort beroep geplaatst in rangorde (1991)

\begin{tabular}{lcl}
$\begin{array}{l}\text { Gewest Maastricht } \\
\text { opleidingsniveau }\end{array}$ & $\begin{array}{l}\text { Belgisch Limburg } \\
\text { opleidingsniveau }\end{array}$ & $\begin{array}{l}\text { Gewest Aken } \\
\text { soort beroep }\end{array}$ \\
\hline 2 & 1 & $\begin{array}{l}\text { Facharbeiter/qualifiziert } \\
\text { nicht Facharbeiter }\end{array}$
\end{tabular}
* Een verklaring van de cijfers waarmee de opleidingscategorieën worden aangeduid zijn in tabel 15
weergegeven.

Op de Euregionale arbeidsmarkt blijken zich knelpunten in de vacaturevervulling voor te doen voor vacatures met de onderste twee opleidingscategorieën als kwalificatievereisten. Alleen in het Belgische gedeelte staan vacatures voor ongeschoolden aan kop in de gegeven rangorde. Vooral vacatures in de beroepsgroep techniek leveren moeilijkheden bij de vacaturevervulling. Dat blijkt duidelijk voor de Belgische deelregio, waar een groot aandeel moeilijk vervulbare vacatures met een technische opleiding als kwalificatievereiste bestaat. Het is duidelijk geworden dat het merendeel van de moeilijk vervulbare vacatures dezelfde opleidingscategorieën als vereiste stellen als het grootste aandeel van de openstaande vraag.

Uit de analyse van de openstaande en moeilijk vervulbare vacatures blijkt dat de deelarbeidsmarkten van de Euregio in de desbetreffende landen, ongeveer hetzelfde beeld vertonen. $\mathrm{Er}$ is sprake van een relatief grote openstaande vraag in de metaal, handel en algemene diensten in de gehele Euregio Maas-Rijn; en in de bouw en horeca ${ }^{35}$ in het Nederlandse en Belgische gedeelte. De problemen blijken vooral op het gebied van de bouw,

34. De gemiddelde vervullingsquote voor het Gewest Aken bedraagt $75 \%$ en is hiermee ook duidelijk groter dan die genoemd in tabel IV voor het Gewest Maastricht.

35. Diensten aan de privé vallen bij de indeling in sectoren onder de horeca. 
metaal en techniek te liggen. In de bouwsector is volgens het RBA Zuid-Limburg sprake van een "chronisch tekort aan vakmensen". De voortdurend ingediende traditionele bouwvacatures blijken moeilijk vervulbaar. Voor de metaal geldt in feite hetzelfde, maar hier is er wel sprake van een afname van het aantal bij het arbeidsbureau geregistreerde moeilijk vervulbare vacatures. Vermoed wordt dat werkgevers met name die vacatures indienen, waarvoor de kans bestaat dat de arbeidsbureaus kunnen bemiddelen en kunnen zorgen voor vervulling van de vacatures. Er bestaan moeilijk vervulbare vacatures voor lassers, bankwerkers, pijpenmonteurs, electromonteurs, pijpfitters en spuiters. Het aanbod uit het reguliere onderwijs voor deze vacatures stagneert, onder andere door het slechte imago van de sector ${ }^{36}$. In de handel spelen twee problemen: ten eerste de nadelen van de ontgroening van de beroepsbevolking. Ten tweede komen de eisen van de werkgevers die niet altijd overeen met de kwalificaties van het arbeidsaanbod. Zo komen leeftijdseisen en het aantal te werken uren vaak niet overeen. Verder komen vacatures in deze sector veelal onverwacht open te staan en moeten ze snel opgevuld worden. Door toeristische activiteiten in de Euregio Maas-Rijn speelt de horeca een belangrijke rol op de arbeidsmarkt. Vanwege het waarschijnlijk bestaan van een grijs/zwart circuit, is de situatie in deze sector minder doorzichtig. Desondanks is wel duidelijk dat de problemen doorgaans op het vlak van het seizoenswerk liggen en dat de eisen van werkgevers en werknemers op het gebied van het aantal te werken uren en loonniveau niet op elkaar aansluiten. Vooral vacatures voor kok zijn (in het hoogseizoen) moeilijk vervulbaar.

Enige verschillen op het gebied van de vacatureproblematiek tussen Nederlands en Belgisch Limburg en het Duitse Aken zijn er wel. Zo zijn er in Duitsland relatief veel moeilijkheden bij de vervulling van vacatures voor ongeschoolden ${ }^{37}$. Het betreft hier vuil en slecht betaald werk, dat bovendien vaak in ploegen- cq. nachtdiensten plaatsvindt. De lonen liggen beneden het niveau van het Nederlandse minimumloon en werkloosheidsuitkering. Een gedeelte van de oorzaak van het relatief grote aantal openstaande vacatures voor ongeschoolden ligt waarschijnlijk in het in het feit dat er in Duitsland geen uitzendbureaus zijn. In de Duitse detailhandel bestaan ten opzichte van Nederland veel vacatures voor oudere, opgeleide vrouwen; deze worden in de BRD als "klantvriendelijk" beschouwd, dit enigszins in tegenstelling tot Nederland, waar veelal de voorkeur aan jongere meisjes wordt gegeven. Andere problemen doen zich voor in de administratieve sector. De Duitse werkgevers stellen vrij hoge kwalificatievereisten, waardoor het moeilijk is om aan een geschikt arbeidsaanbod te komen. In het algemeen wordt in deze sector de tweetaligheid van Nederlanders zeer op prijs gesteld. Dat heeft er toe geleid dat in de im- en exportsector en in de transportbedrijven in het "Arbeitsamtbezirk Aachen" zo'n 80\% Nederlanders werken. Met dat laatste wordt duidelijk dat knelpunten in een deelarbeidsmarkt uiteindelijk kunnen leiden tot de inzet van arbeid uit buurlanden.

36. RBA Zuid Limburg, Kwalitatieve voortgangsrapportage 1991.

37. Uitspraak Arbeitsamt Aachen; idem. Euregioconsulent; overigens blijkt niet uit voorgaande analyse dat de problemen op dit gebied groter zijn dan in de twee andere delen, integendeel daar lijken de problemen juist groter. 


\subsection{Loonstructuren en de vacatureproblematiek}

Bij een analyse van de vacatureproblemen binnen de Euregio Maas-Rijn bleken voor dezelfde beroepsgroepen relatief veel openstaande vacatures voor te komen als verhoudingsgewijs veel moeilijk vervulbare vacatures te bestaan. Het betreft hier vooral de beroepsgroepen metaal, handel en de administratieve sector, en in mindere mate de bouw, horeca en techniek. Wellicht bestaat er binnen de genoemde beroepsgroepen werk op minimumloonniveau. Dat toont evenwel geen duidelijke relatie met de huidige Nederlandse loonstructuur. Opvallend is het relatief kleine aantal openstaande vacatures in de Belgische deelregio (zie tabel 13). Dat is gedeeltelijk te verklaren met de vrij grote vervullingsquotes die in dit land bestaan, zoals weergegeven in tabel V, bijlage B. Echter, de gemiddelde vervullingsquote voor het Duitse gedeelte bedraagt $75 \%$ en is vergeleken met de Nederlandse waarde ook vrij groot. Hier kan een mogelijke relatie gelegd worden met de loonstructuur zoals beschreven in deel 1 van dit onderzoeksverslag. Daarin werd immers duidelijk dat de replacementratio's in Nederland groter zijn dan in de twee andere landen. Blijkbaar gaat een relatief grote replacementratio in Nederland samen met een lage gemiddelde vervullingsquote.

In de vergelijking van de vacatureproblemen naar kwalificatieniveau kwam naar voren dat er in het Nederlandse gedeelte van de Euregio relatief veel openstaande vacatures bestaan voor ongeschoolden. Ook in de Belgische regio betreft het grootste aandeel van de openstaande vacatures, de vacatures waarvoor het laagste onderste kwalificatieniveau wordt vereist, echter in mindere mate dan in de Nederlandse deelregio. In de Duitse deelregio stelt het merendeel van de openstaande vraag daarentegen het tweede niveau ('Ausbildung, Lehre') als kwalificatievereiste. Hiermee is duidelijk dat er in Nederland meer vacatures op ongeschoold niveau bestaan dan in de twee andere landen. Dit zou verklaard kunnen worden uit de in hoofdstuk 4 berekende replacementratio's. De relatief grote replacementratio's voor potentiële werknemers op minimumloonniveau in Nederland leiden in dat geval tot betrekkelijk veel openstaande vacatures. 


\section{WERKLOOSHEID}

\subsection{Werkloosheid in de Euregio Maas-Rijn}

Op basis van de analyse van de bestaande replacementratio's in Nederland in deel 1 is geconcludeerd dat er mogelijk een relatie bestaat met de werkloosheidscijfers. Dit is de reden dat hier een gedeelte aan werkloosheid wordt gewijd, ondanks de al genoemde cijfers in hoofdstuk 5 (tabel 11). De in hoofdstuk 5 vermelde cijfers zijn weergegeven vanwege hun actualiteit, maar zijn niet geharmoniseerd, afkomstig van verschillende bronnen en derhalve niet onderling vergelijkbaar. In tabel 18 wordt een vergelijking op basis van wel geharmoniseerde werkloosheidsgegevens gemaakt.

Tabel 18 Werkloosheidspercentages op nationaal en regionaal niveau voor 1990 (geharmoniseerde cijfers)*

\begin{tabular}{cccccc}
\hline $\begin{array}{c}\text { Nederland } \\
\%\end{array}$ & $\begin{array}{c}\text { Limb.(NL) } \\
\%\end{array}$ & $\begin{array}{c}\text { België } \\
\%\end{array}$ & $\begin{array}{c}\text { Limb.(B) } \\
\%\end{array}$ & $\begin{array}{c}\text { BRD** } \\
\%\end{array}$ & $\begin{array}{c}\text { Gewest Aken } \\
\%\end{array}$ \\
\hline 8.0 & 7.5 & 7.6 & 8.8 & 6.9 & 7.1 \\
\hline
\end{tabular}

Bron: ETIL-SEV'91

* Het geharmoniseerde EG werkloosheidscijfer beschouwt een individu als werkloos wanneer hij/zij minimaal de veertienjarige leeftijd heeft bereikt, geen werk heeft, actief op zoek is naar een baan en onmiddellijk inzetbaar is. Het werkloosheidspercentage wordt gedefinieerd als het aandeel werklozen in de beroepsbevolking (exclusief het leger als werkgever).

* * Voor de BRD is uitgegaan van het werkloosheidscijfer voor de deelstaat Nordrhein-Westfalen.

De regionale werkloosheidscijfers (van 1990) van het Nederlandse Limburg, (7.5\%), en dat van het Duitse gedeelte van de Euregio, (7.1\%), lopen niet veel uiteen. Het percentage voor Belgisch Limburg ligt echter wel wat hoger, $(8.8 \%)$. Wat de nationale/regionale vergelijking betreft, geldt alleen voor het Nederlandse deel van de Euregio dat de nationale ${ }^{38}$ werkloosheid zich op een hoger niveau dan de (Eu)regionale werkloosheid bevindt.

Aangezien in de analyse van de loonstructuren onderscheid is gemaakt naar leeftijdscategorieën is het van belang dit voor de werkloosheidscijfers ook te doen. Tabel 19 geeft de relatieve jeugdwerkloosheid voor de beschouwde regio's ${ }^{39}$ weer. Het betreffen hier geharmoniseerde gegevens, waardoor de cijfers van de afzonderlijke regio's onderling vergeleken kunnen worden.

38. C.q. op deelstaatniveau voor de Duitse deelregio.

39. Het werkloosheidscijfer voor de Nederlandse regio betreft hier heel Limburg in plaats van het RBA gebied Zuid Limburg. 
Tabel 19 Jeugdwerkloosheid voor jongeren t/m 24 jaar, 1989 (geharmoniseerde cijfers)

\begin{tabular}{llc}
$\begin{array}{l}\text { Ned. Limburg } \\
\%\end{array}$ & $\begin{array}{c}\text { Belg. Limburg } \\
\%\end{array}$ & $\begin{array}{c}\text { Gewest Aken } \\
\%\end{array}$ \\
\hline 17.0 & 14.7 & 6.5 \\
\hline
\end{tabular}

Bron: ETIL (1990) Vraag en aanbod op de arbeidsmarkt in internationaal perspectief. p.23.

In de vergelijking van de jeugdwerkloosheidspercentages voor de drie beschouwde deelarbeidsmarkten komt Nederlands Limburg naar voren met het grootste percentage. De jeugdwerkloosheid in het Duitse deel is opvallend lager dan in beide andere regio's. Tabel 20 laat het aandeel jongeren tot en met 24 jaar in de beroepsbevolking zien.

Tabel 20: Relatief aandeel jongeren t/m 24 jaar in de beroepsbevolking $(1990)^{40}$

\begin{tabular}{|c|c|c|c|}
\hline \multicolumn{2}{|c|}{$\begin{array}{l}\text { Ned. Limburg } \\
\%\end{array}$} & \multirow{2}{*}{$\begin{array}{l}\text { Belg. Limburg } \\
\% \\
14\end{array}$} & \multirow{2}{*}{$\begin{array}{c}\begin{array}{c}\text { Gewest Aken* } \\
\%\end{array} \\
17\end{array}$} \\
\hline 19 & & & \\
\hline Bron: & $\begin{array}{l}\text { Voor } h \\
\text { deelsta } \\
\text { van de } \\
\text { Regiona }\end{array}$ & $\begin{array}{l}\text { eel jongeren i } \\
\text { deelstaat is }\end{array}$ & $\begin{array}{l}\text { iet bekend, wel voor de } \\
\text { zen voor het Duitse deel }\end{array}$ \\
\hline
\end{tabular}

Wanneer de jeugdwerkloosheidscijfers gerelateerd worden aan het aandeel van jongeren in de beroepsbevolking, blijkt de jeugdwerkloosheid in het Nederlandse en Belgische Limburg van vergelijkbare grootte. Opvallend is echter de relatief zeer lage jeugdwerkloosheid in het Duitse deel van de Euregio. Geconcludeerd kan worden dat de werkloosheidscijfers voor de gehele beroepsbevolking in de deelgebieden van de Euregio Maas-Rijn van vergelijkbare grootte zijn, maar dat de jeugdwerkloosheid in het Duitse deel duidelijk lager is dan in de beide Limburgen. De jeugdwerkloosheid in de Nederlandse deelregio is het grootst.

40. De duur van de leerplicht ontloopt elkaar niet veel voor de betreffende landen, namelijk: Nederland 5-16 jaar gevolgd door 2 jaar verplicht deeltijdonderwijs voor diegenen
België 6-18 jaar waarvan de laatste 2 jaar eventueel in de vorm van deeltijdonderwijs
BRD 6-15/16 jaar afhankelijk van de deelstaat geldt de leerplicht tot 15 of 16 jaar

Bron: Education and Training (1985) EUROSTAT 3C.--- 


\subsection{Werkloosheid en loonstructuren}

Bij een analyse van de loonstructuren werd ten eerste duidelijk dat de replacementratio's voor Nederland groter zijn dan voor België en de BRD en ten tweede dat de Nederlandse replacementratio's voor jeugdigen vrij groot zijn en bovendien groter zijn dan voor volwassenen en ook duidelijk groter zijn dan voor leeftijdgenoten in de beide andere twee landen. Conform de "job search"theorie kunnen deze twee uitkomsten gevolgen hebben voor de werkloosheidscijfers van Nederland. In 7.1 is geconstateerd dat de totale werkloosheid voor alle drie de (Eu)regionale arbeidsmarkten van vergelijkbare grootte is. Blijkbaar hebben de relatief grote replacementratio's voor Nederland geen duidelijk effect op de werkloosheid nagelaten. Bij de jeugdwerkloosheid is dat echter wel het geval. Er is vastgesteld dat de jeugdwerkloosheid in de Duitse deelregio duidelijk lager is dan in de andere twee delen. Aangenomen kan worden dat het merendeel van de jongeren alleenstaand is, derhalve moet hier uitgegaan worden van de replacementratio's voor alleenstaanden. Voor deze categorie werd in deel 1 duidelijk dat de replacementratio's in Nederland en België groter zijn dan in de $\mathrm{BRD}^{41}$. Dat betekent dat de afstand tussen het netto minimumloon en uitkering in de BRD groter is dan in de twee andere landen. De relatief zeer lage jeugdwerkloosheid in het Duitse gedeelte kan derhalve in verband worden gebracht met de relatief lage replacementratio's. Wel moet hier opgemerkt worden dat institutionele factoren hierbij mogelijk ook een rol spelen; vooral het leerlingwezen in Duitsland is daarbij van belang.

41. M.u.v. jongeren met een wachtuitkering in België; dit doet echter niets af aan de geconstateerde relatie, omdat aangenomen kan worden dat deze jongeren thuiswonend zijn. 


\section{GRENSARBEID}

\subsection{Grensarbeid binnen de Euregio Maas-Rijn}

Wanneer er knelpunten op een arbeidsmarkt binnen een deelregio optreden, mag aangenomen worden dat werkgevers en werknemers naar oplossingen zoeken op een aangrenzende arbeidsmarkt. Voor zover er wordt gezocht naar banen of arbeidskrachten over de landsgrenzen, ontstaat er grensarbeid, ofwel pendelarbeid. Het CBS hanteert de volgende definitie van grensarbeiders: grensarbeiders zijn werknemers die in het ene land wonen en in het andere werken, ook al keren ze wellicht niet dagelijks terug naar het land waar zij woonachtig zijn (CBS Statistiek Grensarbeid, 1991).

Het totale aantal werknemers dat pendelt tussen "woon-en werkland" wordt in Van Dam en De Grip (1991) op zo'n 1 a $2 \%$ van de beroepsbevolking geschat. Met het aantal grensarbeiders kunnen binnen de Euregio de zogenaamde pendelstromen worden onderscheiden. Tabel 21 geeft een beeld van de omvang van de verschillende pendelstromen binnen de Euregio MaasRijn. Deze cijfers hebben echter twee tekortkomingen. Ten eerste zijn de gegevens over het aantal werknemers dat in het buitenland werkzaam is, via enquêtering afkomstig van de ziekenfondsen en derhalve niet volledig. Echter, volledige informatie over het aantal grensarbeiders is niet beschikbaar. Ten tweede zijn voor Belgisch Limburg alleen gegevens van het (arbeidsbureau)gewest Hasselt beschikbaar en ontbreken dus cijfers van het arbeidsbureau Tongeren. Ook dit is niet onoverkomelijk, omdat wel bekend is dat de hoeveelheid pendel vanuit Nederland naar het (arbeidsbureau)gewest Tongeren verwaarloosbaar klein is ${ }^{42}$.

Tabel 21 Aantal grensarbeiders in de drie deelregio's (31-03-1991)

\begin{tabular}{|c|c|c|c|}
\hline woonachting in & $\begin{array}{l}\text { Zuid-Limburg } \\
\text { (NL) }\end{array}$ & $\begin{array}{l}\text { Belgisch } \\
\text { Limburg }\end{array}$ & $\begin{array}{l}\text { Gewest } \\
\text { Aken }\end{array}$ \\
\hline
\end{tabular}

werkzaam in

$\begin{array}{lrrr}\text { Zuid-Limburg } & - & 2730 & 370 \\ \text { Belgisch Limburg } & 500 & - & - \\ \text { Gewest Aken } & 3940 & & -\end{array}$

Bron: CBS Statistiek Grensarbeid; de cijfers zijn afgerond op tientallen.

42. De gegevens over pendelarbeid naar het arbeidsbureaugewest Tongeren worden niet bekend gemaakt in verband met de bestaande geheimhoudingsplicht. De genoemde geheimhoudingsplicht treedt juist in werking door het zeer kleine aantal pendelaars in de genoemde regio (zie CBS Statistiek Grensarbeid, 1991). 
Ondanks de genoemde tekortkomingen van de cijfers over het grensoverschrijdend werkverkeer, kan toch een redelijk beeld worden verkregen van de bestaande pendelstromen. Wel moet worden benadrukt dat tabel 21 niet meer dan een indicatie voor de pendelstromen binnen de Euregio Maas-Rijn vormt.

De bovenstaande tabel laat alleen de pendel binnen de Euregio zien. Daarbij zijn de stromen tussen België en de BRD niet aangegeven. Aangenomen kan worden dat het hier om verwaarloosbaar kleine aantallen gaat (CBS Statistiek Grensarbeid, 1991; Arbeitsamt Aachen). Uit tabel 22 blijkt nog eens dat de pendelstromen vooral oostwaarts zijn gericht (zie ook: Van Dam en De Grip, 1991). Saldering levert het volgende beeld:

Tabel 22 Pendelsaldi binnen de Euregio

\begin{tabular}{llll}
\hline & $\begin{array}{l}\text { Zuid-Limburg } \\
\text { (NL) }\end{array}$ & $\begin{array}{l}\text { Belgisch } \\
\text { Limburg }\end{array}$ & $\begin{array}{l}\text { Gewest } \\
\text { Aken }\end{array}$ \\
\hline $\begin{array}{l}\text { aantal } \\
\text { grensarbeiders }\end{array}$ & -1710 & -2230 & +3570 \\
\hline
\end{tabular}

Bron: bewerking van gegevens van CBS Statistiek Grensarbeid.

De pendelsaldi voor de beide Limburgen zijn uitgaand; voor het Duitse deel is de pendel per saldo landinwaarts gericht. Nogmaals moet hier echter benadrukt worden dat hier niet meer dan een globale indruk over de grensarbeid wordt gegeven en dat betrouwbare gegevens ontbreken.

In een onderzoek uitgevoerd door het Provinciaal Christelijk Vakverbond Limburg (ACV), een Belgisch Limburgse vakbond, wordt een aantal kenmerken van grensarbeiders aangeduid. De bestudeerde populatie in dit onderzoek is echter betrekkelijk klein, namelijk 67 grensarbeiders aangesloten bij het ACV (provincie Limburg) (Goethals, 1990). Het aandeel ongeschoolden in de populatie bleek klein $(3 \%)$, het aantal pendelaars met een diploma lager onderwijs bedroeg $18 \%$, met een diploma lager secundair onderwijs $49 \%$, waarvan weer $60 \%$ een technische opleiding had. Het aandeel met een diploma hoger secundair onderwijs was $23 \%$, waarbij het in $75 \%$ van de gevallen om een technische richting ging. Bovendien volgde $68 \%$ van de ondervraagde populatie een bijscholingscursus. De geënquêteerden bleken voornamelijk werkzaam in de metaal $(54 \%)$, steen en cementindustrie $(20 \%)$, chemie, textiel, en de dienstverlening.

Een aantal redenen om in het buitenland, voornamelijk Nederland, te gaan werken, worden gegeven: betere arbeidsvoorwaarden, geen werk kunnen vinden in België en de betere vooruitzichten in Nederland. Onder de nadelen van het werken als grensarbeider werden een lager bruto loon, naast andere factoren als belastingen, ziekteverzekering en schommelende 
wisselkoersen gezien.

Tabel 23 geeft de leeftijdskenmerken van arbeiders pendelend tussen Nederland, België en de BRD (op nationaal niveau) weer. Wellicht kan op basis van deze informatie een groei-indicator worden verkregen van de kans dat grensarbeiders het minimumloon verdienen. Aangenomen kan worden dat dit vooral werknemers in de jongere leeftijdscategorieën zullen zijn.

De tabel geeft aan dat de meerderheid van het aantal grensarbeiders dat werkzaam is in Nederland, in de leeftijdscategorie 25-34 jaar valt. De "uitgaande" pendelaars naar België en de BRD zijn het merendeel 35-44 jarigen. Verwacht mag worden dat in iedere leeftijdscategorie relatief meer weinig "minimumloners" zijn. Verdere conclusies worden in het volgende gedeelte behandeld. In ieder geval is duidelijk geworden dat er sprake is van een oostwaarst gerichte pendelstroom, met een ingaande pendelstroom van merendeel 25-34 jarigen en een uitgaande van 35-44 jarigen in het Nederlandse gedeelte van de Euregio Maas-Rijn.

Tabel 23 Relatieve aandeel grensarbeiders naar leeftijdscategorie in het totale aantal grensarbeiders (1991)

\begin{tabular}{lcccc}
\hline grensarbeiders: & $\begin{array}{c}20-24 \\
\%\end{array}$ & $\begin{array}{c}25-34 \\
\%\end{array}$ & $\begin{array}{c}35-44 \\
\%\end{array}$ & $\begin{array}{c}\text { overig } \\
\%\end{array}$ \\
\hline & & & & 69 \\
in Ned wonend, werkzaam in België: & 10 & 29 & 30 & 81 \\
in België wonend, werkzaam in Ned: & 16 & 40 & 25 & 68 \\
in Ned. wonend, werkzaam in BRD: & 10 & 27 & 31 & 81 \\
in BRD wonend, werkzaam in Ned: & 14 & 41 & 26 & \\
\end{tabular}

Bron: CBS Statistiek Grensarbeid, 1991

\subsection{Een vergelijking van de gemiddelde bruto Ionen}

In de vorige paragraaf werd duidelijk dat waarschijnlijk weinig grensarbeiders werk op minimumloonniveau verrichten. Misschien dat de gemiddelde bruto loonniveaus de waargenomen pendelstromen binnen de Euregio Maas-Rijn beter kunnen verklaren. In tabel 24 worden de gemiddelde bruto loonniveaus per bedrijfstak en voor alle bedrijftakken samen weergegeven.

De niveaus van de gemiddelde bruto lonen in Nederland zijn hoger dan in België (94), en in de BRD (101) weer hoger dan in Nederland. Daarmee kan dus inderdaad de oostwaarts gerichte pendelstroom binnen de Euregio verklaard worden. De tabel laat verder zien dat het gemiddelde bruto loon in de Nederlandse nijverheid duidelijk hoger is dan in België en iets lager dan in de BRD. Wanneer de (Belgische) term "bedienden" als omschrijving voor de gehele dienstensector opgevat wordt, blijkt dat het gemiddelde loonniveau in deze sector in Nederland vergelijkbaar is met het Belgische niveau (99), maar lager is dan in de BRD (104). 
Het is mogelijk dat de bruto loonniveaus een rol spelen bij de vacatureproblemen binnen de Euregio Maas-Rijn. Zo is in hoofdstuk 6 vastgesteld dat het aantal openstaande vacatures in de nijverheidssector in België relatief groot is en in de dienstensector daarentegen juist klein is. Het relatief lage bruto loonniveau in de nijverheid in België kan tot een grote openstaande vraag in deze sector geleid hebben. Het loonniveau in de Belgische dienstensector is vergelijkbaar met dat in Nederland en naar Belgische begrippen relatief hoog ten opzichte van het gemiddelde landelijke loonniveau, terwijl er in deze sector juist sprake is van een kleine openstaande vraag.

Tabel 24 Gemiddelde bruto loonniveaus naar bedrijfstak in België en Duitsland in vergelijking met Nederland (1990); indexcijfers met Nederland $=100$

België BRD

\begin{tabular}{lr} 
arbeiders: & \\
gehele nijverheid & 94 \\
delfstoffenwinning * & 77 \\
nijverheid & 94 \\
bouwnijverheid & 93 \\
bedienden: & \\
groothandel & 95 \\
detailhandel & 96 \\
bankwezen* & 99 \\
verzekeringswezen & 107 \\
\hline & \\
totaal & 94 \\
& \\
\hline * exclusief elektriciteit, gas, water, stoom & \\
* * exclusief centrale banken & \\
Bron: Bewerking van: EUROSTAT 3C (1991) Earnings. I/1, p.5 + 239.
\end{tabular}

Er moet hier wel worden opgemerkt dat bij het leggen van verbanden tussen de bruto loonniveaus en het voorkomen van grensarbeid, onder andere de belastingwetgeving van groot belang is. Tussen Nederland en België bestaat sinds 1970 een belastingverdrag. Daarin is het recht op belastingheffing over het inkomen geregeld. Deze komt in het geval van grensarbeid tussen Nederland en België toe aan het woonland. In het geval van de Nederlands-Duitse pendel, heeft daarentegen volgens het sinds 1959 bestaande Nederlands-Duitse belastingverdrag, juist het werkland het heffingsrecht. Met deze informatie wordt duidelijk dat het eenvoudiger is om een relatie tussen de gemiddelde bruto loonniveaus en de bestaande pendelstromen tussen Nederland en België te leggen, dan voor de BRD, omdat het fiscale regime voor de eerstgenoemde grensarbeiders niet verandert.

In paragraaf 8.1 en 8.2 werd geconcludeerd dat er relatief weinig pendel binnen de Euregio Maas-Rijn plaatsvindt. Daarbij gaat het bovendien merendeels niet om werk op minimumloonniveau. Met de vergelijking van de gemiddelde bruto loonniveaus tussen Nederland, België 
$-39-$

en de BRD kan de oostwaarts gerichte pendelstroom verklaard worden. Daarnaast bestaat er op het terrein van de vacatureproblematiek mogelijk een relatie tussen de loonniveaus in de Belgische nijverheid en dienstensector, en de relatief grote openstaande vraag in die nijverheidsector en het juist kleine aantal openstaande vacatures in de dienstensector. 


\section{CONCLUSIES}

Met de vergelijking van de netto minimumloonniveaus van Nederland met België en de BRD is duidelijk geworden dat deze bedragen voor jeugdigen in Nederland betrekkelijk laag zijn. De minimumloonniveaus voor volwassenen blijken sterk afhankelijk te zijn van de leefsituatie. De bedragen voor alleenstaanden in Nederland liggen tussen de hogere Belgische en lagere Duitse bedragen in; voor een echtpaar zonder kinderen is het Nederlandse niveau hoger dan in de beide andere landen; en voor een echtpaar met twee kinderen is het niveau in de BRD hoger en in België lager.

Ondanks de door het bestaan van verschillende sociale zekerheidsstelsels, wellicht niet optimale vergelijking kan worden vastgesteld dat de uitkeringsniveaus in Nederland relatief hoog zijn. Voor alle drie de bestudeerde leefsituaties zijn de bedragen hoger dan in de BRD. Voor de Belgische bijstand en werkloosheidsbijstand zijn alleen de bedragen voor jeugdige alleenstaanden hoger, behalve voor jongeren met een wachtuitkering. Dat laatste is bovendien minder relevant, omdat aangenomen kan worden dat deze mensen veelal nog bij hun ouders wonen. $\mathrm{Na}$ de onderlinge vergelijkingen van de netto minimumloon- en uitkeringsniveaus in België, Duitsland en Nederland zijn vervolgens replacementratio's opgesteld ter bepaling van de afstanden tussen de minimumloon- en uitkeringsniveaus in de drie verschillende landen. De replacementratio's in Nederland zijn voor alle drie de leefsituaties groter dan in België en de $B R D$, en nemen af naarmate de leeftijd toeneemt. Hieruit volgt dat de afstanden tussen de netto minimumloon- en uitkeringsniveaus relatief klein zijn in Nederland, en groter worden naarmate de leeftijd toeneemt. De ratio's voor alleenstaanden zijn kleiner dan voor de twee andere gezinssituaties; behalve voor 18 jarigen liggen de ratio's voor alleenstaanden beneden de waarde 1. Vooral voor een echtpaar zonder kinderen blijken de replacementratio's behoorlijk groot te zijn, zo gaat een echtpaar met een 18 jarige kostwinner er $f 805,--$ op achteruit bij het accepteren van een baan op minimumloonniveau. Hier laat het verschijnsel van de "poverty trap" zich gelden. Deze situatie, een echtpaar met een kostwinner van 18 jaar, zal in praktijk echter niet vaak voorkomen. De cijfers voor alleenstaanden zijn derhalve de meest relevante gegevens.

Conform de "job search"theorie konden op basis van de gevonden hoge replacementratio's vacature- en werkloosheidsproblemen verwacht worden. Deze zijn voor de Euregio Maas-Rijn, een arbeidsmarkt bestaande uit deelregio's gelegen in Nederland, België en de BRD, onderzocht. Als eerste werd de relatie tussen de relatief kleine openstaande vraag en de gemiddeld grote vervullingsquote in het Belgische gedeelte van de Euregio Maas-Rijn en de betrekkelijk grote gemiddelde vervullingsquote het Duitse gedeelte, en in vergelijking met Nederland lage replacementratio's in beide regio's vastgesteld. Daarnaast kwam bij de vergelijking van de vacatureproblemen naar kwalificatieniveau naar voren, dat de relatief grote replacementratio's voor potentiële werknemers op minimumloonniveau een verklaring kunnen geven voor een relatief grote openstaande vraag op ongeschoold niveau.

Vervolgens is in hoofdstuk 7 vastgesteld dat er enerzijds een relatie bestaat tussen de lage 
replacementratio's voor jongeren in de BRD ten opzichte van Nederland en de opvallend lage jeugdwerkloosheid in het Duitse gedeelte van de Euregio. Anderzijds bleek er een verband te bestaan tussen de relatief hoge replacementratio's in Nederland en de grote jeugdwerkloosheid in Zuid-Limburg. Op basis van de gegevens omtrent de bestaande jeugdwerkloosheid kan worden geconcludeerd, dat door de huidige hoge replacementratio's voor jongeren, waarna er verhoudingsgewijs veel op minimumloonniveau werken, jongeren waarschijnlijk minder geneigd zullen zijn een vacante baan te accepteren.

Bij de analyse van grensarbeid binnen de Euregio Maas-Rijn kwam naar voren dat er relatief weinig grensarbeid plaatsvindt. Bovendien gaat het waarschijnlijk doorgaans niet om werk op minimumloonniveau. $\mathrm{Er}$ is derhalve geen aanwijzing voor een relatie met de replacementratio's zoals die in deel 1 van het rapport zijn berekend. Wel is het mogelijk op basis van de vergelijking van de gemiddelde bruto loonniveaus in Nederland, België en de BRD, de oostwaarts gerichte pendelstroom binnen de (Eu)regio te verklaren. Daarnaast is er op het terrein van de vacatureproblematiek mogelijk sprake van een relatie tussen de bruto loonniveaus in de Belgische nijverheid en dienstensector, en de relatief grote openstaande vraag in de nijverheidsector en het juist kleine aantal openstaande vacatures in de dienstensector in Belgisch Limburg.

Op basis van de vastgestelde relaties tussen enerzijds de afstanden tussen de netto minimumloon- en uitkeringsniveaus in Nederland, en anderzijds de vacature- en werkloosheidsproblemen, kan men pleiten voor het vergroten van de verschillen tussen de netto minimumloon- en uitkeringsbedragen. In principe is dit op twee manieren mogelijk, namelijk door verlaging van de uitkeringsbedragen, of door verhoging van de minimumloonniveaus. In het laatste geval kunnen de minimumjeugdlonen op een met België en de BRD vergelijkbaar niveau worden gebracht, omdat met name het minimumloonniveau in Nederland sterk verschilt van België en Duitsland. Hierdoor kunnen volgens de "job search"theorie de reserveringslonen van werkloze jongeren verlaagd worden, waardoor de prikkel om zich op de arbeidsmarkt te begeven wordt vergroot, waardoor de jeugdwerkloosheid in Nederland zou kunnen afnemen. Daarnaast zou door een verlaging van de replacementratio's voor potentiële werknemers op minimumloonniveau, het aantal openstaande vacatures op ongeschoold niveau kunnen verminderen. Voor deze werknemers zal het reserveringsloon wellicht tot onder het minimumloonniveau dalen, waardoor het aantrekkelijker wordt zich op de arbeidsmarkt aan te bieden. Hierdoor kunnen de vacatureproblemen in Nederland vervolgens kleiner worden. 


\section{LITERATUUR}

Arbeitsamt Aachen (1991), Sonderuntersuchung Offene Stellen, Aken.

Arbeitsamt Aachen (1992), Daten zum Arbeitsmarkt, Aken.

Arbeitsamt Aachen (1992), Presseinformation, Aken.

Bureau Duitse Zaken (1992), Soziale Sicherheit, Nijmegen.

Centraal Bureau voor de Statistiek (1991), Statistiek Grensarbeid, 's-Gravenhage.

Commissie der Europese Gemeenschappen; Vlaamse Dienst voor de Arbeidsbemiddeling en Beroepsopleiding (1990), Arbeidsbemiddeling aan de grenzen tussen beide Limburgen, Seminarie Tongeren.

Van Dam, J.W., A. de Grip (1991), De Euregionale arbeidsmarkt: van fictie naar werkelijkheid. Researchcentrum voor onderwijs en arbeidsmarkt, Rijksuniversiteit Limburg.

Economisch Technologisch Instituut Limburg (1990), Limburgse arbeidsmarktverkenning 1990, Maastricht.

Europese regelingen: werkloosheid (1991), Provinciaal Christelijk Vakverbond Limburg.

EUROSTAT Statistical Office of European Communities (1991), Labourforce by Age Group 1990, Luxemburg.

EUROSTAT Statistical Office of European Communities (1991), Earnings. 1/1, Luxemburg.

Goethals, L.(1990), Grensarbeid in de Euregio Maas-Rijnland en Saar-Lor-Lux, Hoger Instituut voor de Arbeid, Katholieke Universiteit Leuven.

Gravensteijn-Ligthelm, J.H., H.W. Knol, J. de Koning, A. Verkaik (1990), Werkgelegenheid, loonkosten en produktie in zeven geïndustrialiseerde landen: een sectoranalyse, Nederlands Economisch Instituut, Rotterdam.

Groot, W., G. Jehoel-Gijsbers (21-2-1990), De invloed van uitkeringshoogte op werkloosheidsduur, Economische Statistische Berichten nr. 3746, Rotterdam, p.177-181.

Haagdorens, J. (1991), Bepaling van het bedrag van de werkloosheidsuitkeringen, Provinciaal Christelijk Vakverbond Limburg (België).

Hamermesh, D.S., A. Rees (1988), The Economics of Work and Pay, Harper \& Row, Publishers, New York.

Hanreats, P.C.M., W.C.M. Vermeulen (1990), Vraag en aanbod op de arbeidsmarkt in internationaal perspectief, Economisch Technologisch Instituut Limburg, Maastricht.

Heuvel, K. van den (1992), Minimumbeloningen in de Europese Gemeenschap, Onderzoeks memorandum Ministerie van Sociale Zaken en Werkgelegenheid, 's-Gravenhage.

Hills, J., F. Hubert, H. Tomann, C. Whitehead (1990), Shifting Subsidy from Bricks: and Mortar to People: Experiences in Britain and West Germany, Policy and Politics volume 18, number 3. 
Janssen, P.J.E. (1992), Over de grens gaan; knelpuntanalyse grensarbeid Nederland-België, Gemeente Maastricht.

Korpel, J.H., R.C. van der Mark, M.L.A. Peters (1989), Een internationale vergelijking van de minimumlonen, de inkomensverdeling en de minimumuitkeringen, deel II, Ministerie van Sociale Zaken en Werkgelegenheid, 's-Gravenhage.

Korpel, J.H., R.C. van der Mark, M.L.A. Peters (1989), Een internationale vergelijking van de minimumlonen, de inkomensverdeling en de minimumuitkeringen, Ministerie van Sociale Zaken en Werkgelegenheid, 's-Gravenhage.

Landesamt Nordrhein-Westfalen (1990), Statistik der Arbeitsvermittlung, Düsseldorf.

Landesamt für Datenverarbeitung und Statistik Nordrhein-Westfalen (1991), Entwick/ungen in Nordrhein-Westfalen, Düsseldorf.

Ministerie van Sociale Zaken en Werkgelegenheid (1989), Jaarverslag '88 Arbeidsvoorziening, 's-Gravenhage.

Ministerie van Sociale Zaken en Werkgelegenheid (1989), Jaarverslag '89 Arbeidsvoorziening, 's-Gravenhage.

Ministerie van Sociale Zaken en Werkgelegenheid, Inkomensnota 1992, 's-Gravenhage.

Ministerie van Sociale Zaken en Werkgelegenheid, Rapportage Arbeidsmarkt 1991, 'sGravenhage.

Ministerie van Sociale Zaken en Werkgelegenheid, Algemene bijstandswet 1 januari 1992, 'sGravenhage.

Ministerie van Sociale Zaken en Werkgelegenheid, Minimumloon per 1 januari 1992, 'sGravenhage.

Opheikens, L., H. Neumeister (1989), De Duitse en Nederlandse Sociale Verzekeringen; Een vergelijkend overzicht, EUREGIO, Gronau, Enschede.

Regionaal Bureau voor de Arbeidsvoorziening Zuid-Limburg, Beleidsplan 1992, Maastricht.

Regionaal Bureau voor de Arbeidsvoorziening Zuid-Limburg, Beleidsplan 1992, Maastricht.

Regionaal Bureau voor de Arbeidsvoorziening Zuid-Limburg, Kwalitatieve voortgangsrapportage 1991, Maastricht.

Rijksdienst voor Arbeidsvoorziening (1991), Wegwijs in de werkloosheidswetgeving, (België)

Samuelson, P.A., W.D. Nordhaus (1985), Economics, Mc Graw-Hill International Editions, New York.

Stichting Bureau voor Belgische Zaken de sociale verzekering betreffende, Vergelijkend overzicht 1992, Breda.

Stichting het Nederlands Economisch Instituut (1991), Werkgelegenheid, loonkosten en produktie in zeven geïndustrialiseerde landen: een sectoranalyse, Rotterdam.

Stichting het Nederlands Economisch Instituut (1991), Internationale arbeidsbemiddeling, Rotterdam. 
$-44-$

Verdrag betreffende bureaux voor arbeidsbemiddeling, welke voor hun bemiddeling betaling vragen (herzien) (1990), Brussel.

Vlaamse Dienst voor de Arbeidsbemiddeling en Beroepsopleiding (1991), Analyse Vakaturen '90; Kwalitatief en kwantitatief overzicht afgehandelde vakaturen, Studiedienst Brussel.

Vlaamse Dienst voor de Arbeidsbemiddeling en Beroepsopleiding, Subregionale Tewerkstellingsdienst Tongeren (1991), Maandvers/ag, Tongeren.

Voorlichtingscentrum Sociale verzekering Amsterdam (1992), De kleine Gids voor de Nederlandse sociale zekerheid 1992, Kluwer, Deventer.

Voorlichtingscentrum Sociale verzekering Amsterdam, Stand van zaken bij de sociale verzekeringen en voorzieningen, Amsterdam.

Wirtschaft und Statistik 10 (1991), Wohngeld 1990; Ergebnis der Wohngeldstatistik. 


\section{BIJLAGE A: LOONSTRUCTUUR}

Tabel I Absolute bruto minimumloonniveaus (1992)*

\begin{tabular}{lccc}
\hline leeftijd & $\begin{array}{l}\text { Nederland } \\
\text { (gulden) }\end{array}$ & $\begin{array}{l}\text { België } \\
\text { (Belg.franc) }\end{array}$ & $\begin{array}{l}\text { BRD } \\
\text { (D.Mark) }\end{array}$ \\
\hline & & & 1.918 \\
16 & 736 & 24.286 & 1.918 \\
17 & 843 & 24.286 & 1.918 \\
18 & 971 & 30.114 & 1.918 \\
19 & 1.120 & 33.029 & 2.023 \\
20 & 1.312 & 35.943 & 2.130 \\
21 & 1.546 & 38.857 & 2.130 \\
22 & 1.813 & 39.940 & 2.130 \\
\hline
\end{tabular}

* De bedragen in de tabellen zijn afgerond op gehele cijfers.

Bron: Nederlandse bedragen, SZW; Belgische, Ministerie van Tewerkstelling en Arbeid; Duitse, Lohnvertrag Eisen-, Metall- und Elektroindustrie.

De cijfers in de volgende tabel zijn berekend met behulp van koopkrachtpariteiten. De gehanteerde koopkrachtpariteiten voor 1990 (Eurostat, 1991) zijn gecorrigeerd voor de inflatie in de betreffende landen van $1991^{1}$ :

1 koopkrachtpariteit (PPS) $=\ldots \ldots$.

- Nederland

$f 1.70$

- België

f 32.98

- BRD

$f 1.77$

Tabel II Absolute minimumloonniveaus (1992) in guldens

\begin{tabular}{lccc}
\hline leeftijd & Nederland & België & BRD \\
& & & \\
\hline 16 & 736 & 1.252 & 1.841 \\
17 & 843 & 1.402 & 1.841 \\
18 & 971 & 1.552 & 1.841 \\
19 & 1.120 & 1.703 & 1.841 \\
20 & 1.546 & 1.853 & 2.046 \\
21 & 1.813 & 2.003 & 2.046 \\
\hline 23 & 2.133 & 2.059 & \\
\hline
\end{tabular}

Bron: Nederlandse bedragen, SZW; Belgische, Ministerie van Tewerkstelling en Arbeid; Duitse, Lohnvertrag Eisen-, Metall- und Elektroindustrie.

1. Het inflatiepercentage voor Nederland bedroeg in $19913.75 \%$, voor België $2.8 \%$ en voor de BRD 3.25\%; uit: F. van Lanschot Bankiers nv (01-01-1992) Economische kerngegevens, ESB. Belgische Ambassade, Den Haag. 
De Nederlandse en Belgische bedragen van de netto minimumlonen in de volgende tabellen zijn tot stand gekomen via berekening van de belasting- en premieafdrachten ${ }^{2}$. De Duitse netto minimumloongegevens zijn geschat op basis van een percentage aan belasting-en premieafdrachten $^{3}$. De laatst genoemde methode leidt natuurlijk niet tot de meest optimale netto minimumloongegevens, maar geeft wel een adequate indicatie. Desondanks kan er aan de Nederlandse en Belgische cijfers meer waarde worden gehecht.

Tabel III Absolute netto minimumloonniveaus voor alleenstaanden (1992)

\begin{tabular}{lccc}
\hline leeftijd & $\begin{array}{l}\text { Nederland } \\
\text { (gulden) }\end{array}$ & $\begin{array}{l}\text { België } \\
\text { (Belg.franc) }\end{array}$ & $\begin{array}{l}\text { BRD } \\
\text { (D.Mark) }\end{array}$ \\
\hline & & & \\
16 & 654 & 20.964 & 1.289 \\
17 & 725 & 23.106 & 1.289 \\
18 & 810 & 25.248 & 1.289 \\
19 & 909 & 27.362 & 1.289 \\
20 & 1.036 & 29.349 & 1.360 \\
21 & 1.190 & 31.337 & 1.432 \\
22 & 1.366 & 32.075 & 1.432 \\
23 & 1.578 & 32.075 & 1.432 \\
\hline Bron: & Nederlandse bedragen, SZW; Belgische, Ministerie van Tewerkstelling en Arbeid; Duitse, &
\end{tabular}

Tabel IV Absolute netto minimumloonniveaus voor echtparen (1992)

\begin{tabular}{lccc}
\hline leeftijd & $\begin{array}{l}\text { Nederland } \\
\text { (gulden) }\end{array}$ & $\begin{array}{l}\text { België } \\
\text { (Belg.franc) }\end{array}$ & $\begin{array}{l}\text { BRD } \\
\text { (D.Mark) }\end{array}$ \\
\hline 18 & 909 & 25.248 & 1.289 \\
19 & 1.024 & 27.362 & 1.289 \\
20 & 1.142 & 29.349 & 1.360 \\
21 & 1.286 & 31.337 & 1.432 \\
22 & 1.450 & 32.075 & 1.432 \\
23 & 1.745 & 32.075 & 1.432 \\
\hline
\end{tabular}

Bron: Nederlandse bedragen, SZW; Belgische, Ministerie van Tewerkstelling en Arbeid; Duitse, Lohnvertrag Eisen-, Metall- und Elektroindustrie, Arbeitsamt Aachen.

2. Vergelijkend overzicht van de Nederlandse en Belgische sociale verzekeringswetgevingen voor loontrekkenden per 1 januari 1992. Stichting Bureau voor Belgische Zaken.

3. Arbeitsamt Aachen 
Voor een echtpaar van 20 tot en met 22 jaar is uitgegaan van twee kinderen in de leeftijd van 0 tot 5 jaar. In het geval van een echtpaar ouder dan 23 jaar betreffen het kinderen van 6 tot 11 jaar.

Tabel V Absolute netto minimumloonniveaus voor echtparen met 2 kinderen $(1992)^{4}$

\begin{tabular}{llll}
\hline leeftijd & $\begin{array}{l}\text { Nederland } \\
\text { (gulden) }\end{array}$ & $\begin{array}{l}\text { België } \\
\text { (Belg.franc) }\end{array}$ & $\begin{array}{l}\text { BRD } \\
\text { (D.Mark) }\end{array}$ \\
\hline & & & \\
20 & 1.261 & 31.983 & 2.355 \\
21 & 1.405 & 33.970 & 2.355 \\
22 & 1.569 & 33.970 & 2.355 \\
23 & 1.910 & 34.709 & 2.355
\end{tabular}

Bron: Bewerking van: Nederlandse bedragen, SZW; Belgische, Ministerie van Tewerkstelling en Arbeid; Duitse, Lohnvertrag Eisen-, Metall- und Elektroindustrie, Arbeitsamt Aachen.

Tabel VI Absolute netto minimumloonniveaus voor alleenstaanden; in guldens (1992)

\begin{tabular}{lccc}
\hline leeftijd & Nederland & België & BRD \\
& & & \\
\hline & & & 1.289 \\
18 & 810 & 1.301 & 1.289 \\
19 & 909 & 1.410 & 1.360 \\
20 & 1.036 & 1.513 & 1.432 \\
21 & 1.190 & 1.615 & 1.432 \\
22 & 1.366 & 1.653 & 1.432 \\
\hline
\end{tabular}

Bron: Bewerking van: Nederlandse bedragen, SZW; Belgische, Ministerie van Tewerkstelling en Arbeid; Duitse, Lohnvertrag Eisen-, Metall- und Elektroindustrie, Arbeitsamt Aachen.

4. In de BRD ontvangen uitkeringsgerechtigden en mensen met de laagste inkomens "Wohngeld". Dit is een vergoeding voor de te maken woonkosten. Daarbij wordt ook een vergoeding voor de verwarmingskosten gegeven, deze bedraagt gemiddeld $25 \%$ van het "Wohngeld". De totale vergoeding is afhankelijk van de individuele woon-, leef- en inkomenssituatie en daarom moeilijk vast te stellen. Hier zijn de maximale inkomens waarvoor een woonvergoeding mogelijk is beschouwd en is uitgegaan van een gemiddeld bedrag aan "Wohngeld". De verwarmingskosten zijn echter buiten beschouwing gelaten. Op basis van het bovenstaande is een gemiddeld bedrag aan "Wohngeld" toegerekend aan uitkeringsgerechtigden en echtparen met twee kinderen met genoemd inkomensniveau in de BRD. 
Tabel VII Absolute netto minimumloonniveaus voor echtparen; in guldens (1992)

\begin{tabular}{lccc}
\hline leeftijd & Nederland & België & BRD \\
& & & \\
\hline & & & 1.289 \\
18 & 909 & 1.301 & 1.289 \\
19 & 1.024 & 1.410 & 1.360 \\
20 & 1.142 & 1.513 & 1.432 \\
21 & 1.286 & 1.615 & 1.432 \\
22 & 1.450 & 1.653 & 1.432
\end{tabular}

Bron: Bewerking van: Nederlandse bedragen, SZW; Belgische, Ministerie van Tewerkstelling en Arbeid; Duitse, Lohnvertrag Eisen-, Metall- und Elektroindustrie, Arbeitsamt Aachen.

Tabel VIII Absolute netto minimumloonniveaus voor echtparen met 2 kinderen in guldens (1992)

\begin{tabular}{llll}
\hline leeftijd & Nederland & België & \\
& & & \\
& & & \\
\hline & & & 2.262 \\
20 & 1.261 & 1.649 & 2.262 \\
21 & 1.405 & 1.751 & 2.262 \\
22 & 1.569 & 1.789 & 2.262
\end{tabular}

Bron: Bewerking van: Nederlandse bedragen, SZW; Belgische, Ministerie van Tewerkstelling en Arbeid; Duitse, Lohnvertrag Eisen-, Metall- und Elektroindustrie, Arbeitsamt Aachen.

Tabel IX Netto minimumloonniveaus voor alleenstaanden via indexcijfers; Nederland $=100(1992)^{5}$

\begin{tabular}{lcc}
\hline leeftijd & België & BRD \\
& & \\
\hline & & 197 \\
16 & 165 & 178 \\
17 & 164 & 159 \\
18 & 161 & 142 \\
19 & 155 & 131 \\
20 & 146 & 120 \\
21 & 136 & 105 \\
22 & 121 & 91 \\
\hline 23 & 105 &
\end{tabular}

Bron: Bewerking van: Nederlandse bedragen, SZW; Belgische, Ministerie van Tewerkstelling en Arbeid, Belastingdienst; Duitse, Lohnvertrag Eisen-, Metall- und Elektroindustrie, Arbeitsamt Aachen.

5. De indexcijfers zijn berekend via koopkrachtpariteiten. 
Tabel X Netto minimumloonniveaus voor echtparen via indexcijfers; Nederland $=100(1992)^{6}$

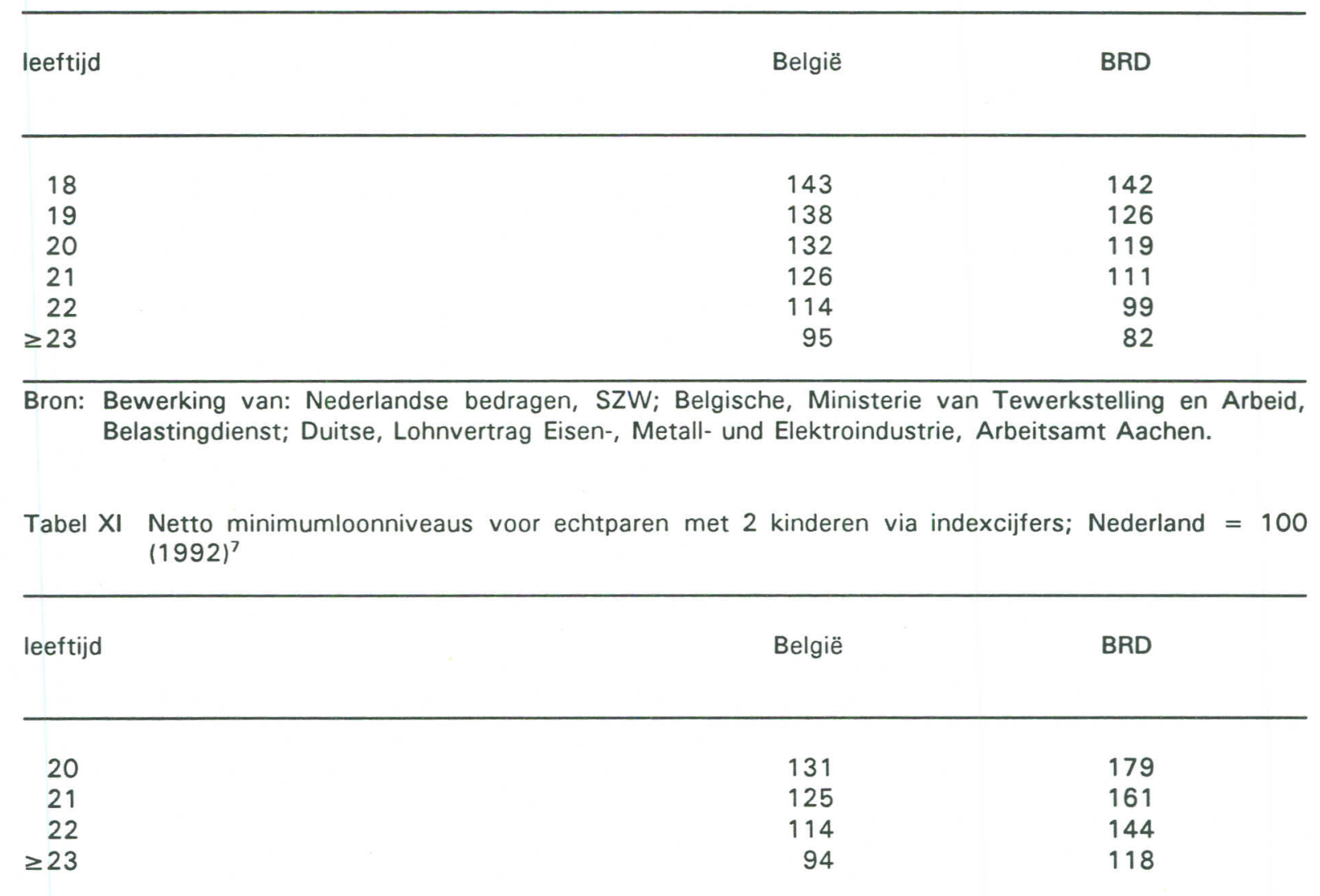

Bron: Bewerking van: Nederlandse bedragen, SZW; Belgische, Ministerie van Tewerkstelling en Arbeid, Belastingdienst; Duitse, Lohnvertrag Eisen-, Metall- und Elektroindustrie, Arbeitsamt Aachen.

6. De indexcijfers zijn berekend via koopkrachtpariteiten.

7. De indexcijfers zijn berekend via koopkrachtpariteiten. 
$-50-$

\section{Uitkeringsniveaus}

Tabel XII Netto minimumuitkeringen voor alleenstaanden (1992)

\begin{tabular}{ccllc}
\hline leeftijd & Nederland & $\begin{array}{l}\text { België8 } \\
\text { (bijstand) } \\
\text { (Belg.franc) }\end{array}$ & $\begin{array}{l}\text { België9 } \\
\text { (werkl.) } \\
\text { (Belg.franc) }\end{array}$ & BRD \\
(Dulden) & Mark) \\
\hline 18 & 838 & & 11.986 & 694 \\
19 & 838 & 18.729 & 11.986 & 694 \\
20 & 838 & 18.729 & 19.604 & 694 \\
21 & 879 & 18.729 & 19.604 & 694 \\
22 & 1.007 & 18.729 & 19.604 & 694 \\
\hline 23 & 1.200 & 19.604 & 694
\end{tabular}

Bron: Bewerking van: Nederlandse bedragen, SZW; Belgische, Ministerie van Tewerkstelling en Arbeid; Duitse, Lohnvertrag Eisen-, Metall- und Elektroindustrie, Arbeitsamt Aachen.

Tabel XIII Netto minimumuitkeringen voor echtparen (1992)

\begin{tabular}{lllll}
\hline leeftijd & Nederland & $\begin{array}{l}\text { België } \\
\text { (bijstand) } \\
\text { (Belg.franc) }\end{array}$ & $\begin{array}{l}\text { België } \\
\text { (werkl.) } \\
\text { (Belg.franc) }\end{array}$ & BRD \\
& & & & \\
\hline & & & & 1.143 \\
18 & 1.714 & 24.972 & 27.404 & 1.143 \\
19 & 1.714 & 24.972 & 27.404 & 1.143 \\
20 & 1.714 & 24.972 & 27.404 & 1.143 \\
21 & 1.714 & 24.972 & 27.404 & 1.143 \\
22 & 1.714 & 24.972 & 27.404 & 1.143
\end{tabular}

Bron: Bewerking van: Nederlandse bedragen, SZW; Belgische, Ministerie van Tewerkstelling en Arbeid; Duitse, Lohnvertrag Eisen-, Metall- und Elektroindustrie, Arbeitsamt Aachen.

8. Aangenomen is dat jongeren van 18 en 19 jaar geen "normale" bijstand ontvangen. Veel van hen zullen nog afhankelijk van hun ouders zijn.

9. Er is voor België van uitgegaan dat werkloze alleenstaande jongeren van 18 en 19 jaar een zogenaamde wachtgelduitkering genieten. Dit is een uitkering voor schoolverlaters die nog niet over een arbeidsverleden beschikken. 
$-51-$

Tabel XIV Netto minimumuitkeringen voor echtparen met 2 kinderen in guldens (1992)

\begin{tabular}{lllll}
\hline leeftijd & Nederland & $\begin{array}{l}\text { België } \\
\text { (bijstand) } \\
\text { (Belg.franc) }\end{array}$ & $\begin{array}{l}\text { België } \\
\text { (werkl.) } \\
\text { (Belg. franc) }\end{array}$ & BRD \\
(D.Mark)
\end{tabular}

Bron: Bewerking van: Nederlandse bedragen, SZW; Belgische, Ministerie van Tewerkstelling en Arbeid; Duitse, Lohnvertrag Eisen-, Metall- und Elektroindustrie, Arbeitsamt Aachen.

Tabel XV Netto minimumuitkeringen voor alleenstaanden in guldens (1992)

\begin{tabular}{lllll}
\hline leeftijd & Nederland & $\begin{array}{l}\text { België } \\
\text { (bijstand) }\end{array}$ & $\begin{array}{l}\text { België } \\
\text { (werkl.) }\end{array}$ \\
\hline & & & & BRD \\
18 & 838 & 965 & 618 & 667 \\
19 & 838 & 965 & 618 & 667 \\
20 & 838 & 965 & 1.011 & 667 \\
21 & 879 & 965 & 1.011 & 667 \\
22 & 1.007 & 965 & 1.011 & 667 \\
$\geq 23$ & 1.200 & 965 & 1.011 & 667
\end{tabular}

Bron: Bewerking van: Nederlandse bedragen, SZW; Belgische, Ministerie van Tewerkstelling en Arbeid; Duitse, Lohnvertrag Eisen-, Metall- und Elektroindustrie, Arbeitsamt Aachen.

Tabel XVI Netto minimumuitkeringen voor echtparen in guldens (1992)

\begin{tabular}{lllll}
\hline leeftijd & Nederland & $\begin{array}{l}\text { België } \\
\text { (bijstand) }\end{array}$ & $\begin{array}{l}\text { België } \\
\text { (werkl.) }\end{array}$ \\
\hline & & & & 1.098 \\
18 & 1.714 & 965 & 1.011 & 1.098 \\
20 & 1.714 & 965 & 1.011 & 1.098 \\
21 & 1.714 & 965 & 1.011 & 1.098 \\
22 & 1.714 & 965 & 1.011 & 1.098 \\
$\geq 23$ & 1.714 & 965 & 1.011 & 1.098
\end{tabular}

Bron: Bewerking van: Nederlandse bedragen, SZW; Belgische, Ministerie van Tewerkstelling en Arbeid; Duitse, Lohnvertrag Eisen-, Metall- und Elektroindustrie, Arbeitsamt Aachen. 
$-52-$

Tabel XVII Netto minimumuitkeringen voor echtparen met 2 kinderen in guldens (1992)

\begin{tabular}{lllll}
\hline leeftijd & Nederland & $\begin{array}{l}\text { België } \\
\text { (bijstand) }\end{array}$ & $\begin{array}{l}\text { België } \\
\text { (werkl.) }\end{array}$ & BRD \\
\hline 20 & 1.833 & 1.751 & 1.877 & 1.509 \\
21 & 1.833 & 1.751 & 1.877 & 1.509 \\
22 & 1.833 & 1.751 & 1.877 & 1.509 \\
$\geq 23$ & 1.879 & 1.751 & 1.877 & 1.577
\end{tabular}

Bron: Bewerking van: Nederlandse bedragen, SZW; Belgische, Ministerie van Tewerkstelling en Arbeid; Duitse, Lohnvertrag Eisen-, Metall- und Elektroindustrie, Arbeitsamt Aachen.

Tabel XVIII Netto minimumuitkeringsniveaus voor alleenstaanden (indexcijfers; Nederland $=100$ )

\begin{tabular}{lccc}
\hline leeftijd & \multicolumn{2}{c}{ België } & BRD \\
& (bijstand) & (werkl.) & \\
& & & \\
& & & 80 \\
18 & 115 & 74 & 80 \\
19 & 115 & 120 & 80 \\
20 & 115 & 115 & 76 \\
21 & 110 & 100 & 66 \\
\hline 23 & 96 & 84 & 56
\end{tabular}

Bron: Bewerking van: Nederlandse bedragen, SZW; Belgische, Ministerie van Tewerkstelling en Arbeid, Belastingdienst; Duitse, Lohnvertrag Eisen-, Metall- und Elektroindustrie, Arbeitsamt Aachen.

Tabel XIX Netto minimumuitkeringsniveaus voor echtparen 1992 via indexcijfers; Nederland $=100$ (1992)

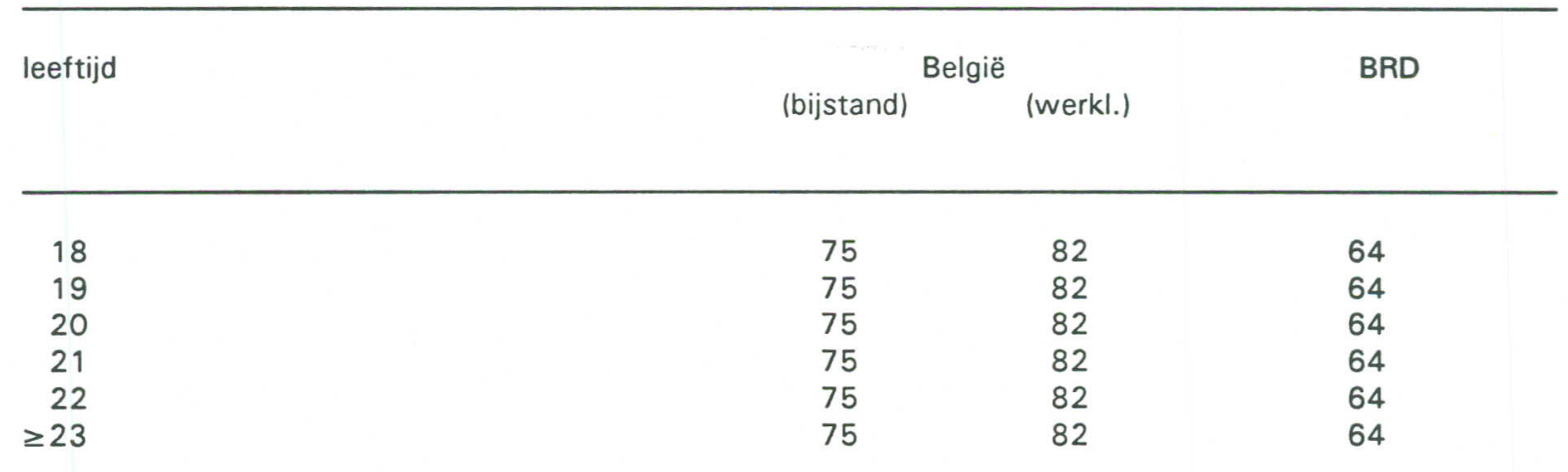

Bron: Bewerking van: Nederlandse bedragen, SZW; Belgische, Ministerie van Tewerkstelling en Arbeid, Belastingdienst; Duitse, Lohnvertrag Eisen-, Metall- und Elektroindustrie, Arbeitsamt Aachen. 
Tabel XX Netto minimumuitkeringsiveaus voor echtparen met 2 kinderen (indexcijfers; Nederland = 100)

leeftijd

$\begin{array}{ll}\text { België } & \\ \text { (bijstand) } & \text { BRD }\end{array}$

\begin{tabular}{llll}
\hline & & & 82 \\
21 & 96 & 102 & 82 \\
22 & 96 & 102 & 82 \\
$\geq 23$ & 96 & 102 & 82
\end{tabular}

Bron: Bewerking van: Nederlandse bedragen, SZW; Belgische, Ministerie van Tewerkstelling en Arbeid, Belastingdienst; Duitse, Lohnvertrag Eisen-, Metall- und Elektroindustrie, Arbeitsamt Aachen.

Om tot een goede vergelijking van de uitkeringsniveaus te komen kunnen de uitkeringen als percentage van het gemiddeld besteedbaar inkomen in de desbetreffende landen worden uitgedrukt. Sociale uitkeringen staan immers niet los van het loonniveau. Het gaat hier niet zozeer om een vergelijking te geven van de verhoudingen tussen uitkeringsbedragen en het gemiddeld besteedbaar inkomen, maar meer om een indruk te geven van de relatieve hoogte van de uitkeringsniveaus bij de voor de bestudeerde landen gemiddeld geldende loonniveau. Tabel XXI geeft hiervan een beeld, waarbij de uitkeringsbedragen op dezelfde wijze zijn samengesteld als in de voorgaande tabellen ${ }^{10}$.

Tabel XXI Netto uitkeringsniveaus als percentage van het gemiddeld besteedbaar inkomen voor 1988; indexcijfers met Nederland $=100$

\begin{tabular}{|c|c|c|c|c|c|c|}
\hline \multirow[t]{3}{*}{ leefsituatie } & \multicolumn{4}{|c|}{ België } & \multicolumn{2}{|c|}{ BRD } \\
\hline & \multicolumn{2}{|c|}{ (bijstand) } & \multicolumn{2}{|c|}{ (werkl.) } & \multirow[b]{2}{*}{$\%$} & \multirow[b]{2}{*}{ index } \\
\hline & $\%$ & index & $\%$ & index & & \\
\hline alleenstaande & 54 & 82 & 57 & 6 & 41 & 62 \\
\hline echtpaar zonder kinderen & 43 & 81 & 48 & 91 & 33 & 62 \\
\hline echtpaar met 2 kinderen & 42 & 84 & 46 & 92 & 40 & 80 \\
\hline
\end{tabular}

Bron: J.H. Korpel et al. (1989) Een internationale vergelijking van de minimumlonen, de inkomensverdeling en de minimumuitkeringen, deel ii. p.135-136.

De tabel laat zien dat de Nederlandse uitkeringen zich relatief op het hoogste niveau bevinden

10. Behalve dan, dat in de vergelijking van de uitkeringsniveaus voor de BRD $25 \%$ verwarmingskosten bij het Wohngeld is betrokken; in dit hoofdstuk zijn deze kosten niet meegenomen in de berekeningen in verband met de internationale vergelijkbaarheid. 
$-54-$

voor alle drie de leefsituaties ${ }^{11}$. Dit sluit aan bij de vergelijking van de uitkeringsniveaus op basis van koopkrachtpariteiten in paragraaf 3.4. Daarin kwam naar voren dat het uitkeringsniveau voor volwassenen (23 jaar en ouder) voor alle leefsituaties in Nederland hoger is dan in beide buurlanden en alleen het bedrag voor een werkloos echtpaar met twee kinderen in België vergelijkbaar is met het niveau in Nederland. Vooral Nederlandse alleenstaanden hebben te maken met een relatief hoog uitkeringsbedrag. Overigens is het aandeel van het uitkeringsbedrag in het gemiddeld besteedbaar inkomen voor alleenstaanden in België en de Bondsrepubliek Duitsland ook het hoogste in vergelijking met de andere twee leefsituaties.

Afstanden netto minimumloon en netto minimumuitkeringen

Volgens de "job search" theorie wordt de replacementratio gedefinieerd als: de verhouding tussen het inkomen in de werkloosheids- en de werksituatie (Groot, W., G. Jehoel-Gijsbers, 1990) Hier wordt de genoemde verhouding bepaald door het netto minimumuitkeringsniveau en het netto minimumloon.

Tabel XXII Replacementratio's en absolute afstanden (in guldens) tussen minimumloon en minimumvitkering voor alleenstaanden (1992)

\begin{tabular}{|c|c|c|c|c|c|c|c|c|}
\hline \multirow[t]{3}{*}{ leeftijd } & \multirow{2}{*}{\multicolumn{2}{|c|}{ Nederland }} & \multicolumn{4}{|c|}{ België } & \multicolumn{2}{|c|}{ BRD } \\
\hline & & & \multicolumn{2}{|c|}{ (bijstand) } & \multicolumn{2}{|c|}{ (werkl.) } & & \\
\hline & $\mathrm{R}$ & $f$ & $\mathrm{R}$ & $f$ & $R$ & $f$ & $R$ & $f$ \\
\hline 18 & 1.03 & $(-28)$ & 0.47 & (684) & 0.78 & (291) & 0.52 & $(622)$ \\
\hline 19 & 0.92 & (71) & 0.44 & (793) & 0.72 & $(400)$ & 0.52 & (622) \\
\hline 20 & 0.81 & (198) & 0.64 & (547) & 0.67 & (502) & 0.49 & (694) \\
\hline 21 & 0.73 & (311) & 0.60 & (650) & 0.63 & (605) & 0.47 & (766) \\
\hline 22 & 0.73 & (359) & 0.58 & (688) & 0.61 & (643) & 0.47 & (766) \\
\hline 23 & 0.76 & (378) & 0.58 & (688) & 0.61 & (643) & 0.47 & (766) \\
\hline
\end{tabular}

Bron: Bewerking van: Nederlandse bedragen, SZW; Belgische, Ministerie van Tewerkstelling en Arbeid, Belastingdienst; Duitse, Lohnvertrag Eisen-, Metall- und Elektroindustrie, Arbeitsamt Aachen.

11. Er is geen verdeling naar leeftijdscategorieën gemaakt, er wordt uitgegaan van volwassenen. 
Tabel XXIII Replacementratio's en absolute afstanden (in guldens) tussen minimumloon en minimumuitkering voor echtparen (1992)

\begin{tabular}{|c|c|c|c|c|c|c|c|}
\hline \multirow[t]{3}{*}{ leeftijd } & \multirow{2}{*}{\multicolumn{2}{|c|}{ Nederland }} & \multicolumn{3}{|c|}{ België } & \multicolumn{2}{|c|}{ BRD } \\
\hline & & & \multicolumn{2}{|c|}{ (bijstand) } & (werkl.) & & \\
\hline & $\mathrm{R}$ & $f$ & $\mathrm{R}$ & $f$ & $\mathrm{R}$ & $\mathbf{R}$ & $f$ \\
\hline 18 & 1.89 & $(-805)$ & 0.99 & (14) & $1.09(-111)$ & 0.85 & (191) \\
\hline 19 & 1.67 & $(-690)$ & 0.91 & (123) & 1.00 & 0.85 & (191) \\
\hline 20 & 1.50 & $(-572)$ & 0.85 & $(226)$ & $0.93(100)$ & 0.81 & (262) \\
\hline 21 & 1.33 & $(-428)$ & 0.80 & (328) & 0.87 (203) & 0.77 & (334) \\
\hline 22 & 1.18 & $(-264)$ & 0.78 & $(366)$ & $0.85 \quad(241)$ & 0.77 & (334) \\
\hline$\geq 23$ & 0.98 & (31) & 0.78 & $(366)$ & $0.85 \quad(241)$ & 0.77 & (334) \\
\hline
\end{tabular}

Bron: Bewerking van: Nederlandse bedragen, SZW; Belgische, Ministerie van Tewerkstelling en Arbeid, Belastingdienst; Duitse, Lohnvertrag Eisen-, Metall- und Elektroindustrie, Arbeitsamt Aachen.

Tabel XXIV Replacementratio's en absolute afstanden (in guldens) tussen minimumloon en minimumuitkering voor echtparen met 2 kinderen (1992)

\begin{tabular}{|c|c|c|c|c|c|}
\hline \multirow[t]{3}{*}{ leeftijd } & \multirow{2}{*}{\multicolumn{2}{|c|}{ Nederland }} & \multicolumn{2}{|c|}{ België } & BRD \\
\hline & & & (bijstand) & (werkl.) & \\
\hline & $\mathrm{R}$ & $f$ & $\mathrm{R} \quad f$ & $\mathrm{R} \quad f$ & $f$ \\
\hline 20 & 1.45 & $(-572)$ & $1.06(-103)$ & $1.14(-228)$ & $1.11(-149)$ \\
\hline 21 & 1.30 & $(-428)$ & 1.00 & $1.07(-126)$ & $1.05 \quad(-77)$ \\
\hline 22 & 1.17 & $(-264)$ & 0.98 & $1.05(-88)$ & $1.10(-145)$ \\
\hline$\geq 23$ & 0.98 & (31) & 0.98 & $1.05 \quad(-88)$ & $1.10(-145)$ \\
\hline
\end{tabular}

Bron: Bewerking van: Nederlandse bedragen, SZW; Belgische, Ministerie van Tewerkstelling en Arbeid, Belastingdienst; Duitse, Lohnvertrag Eisen-, Metall- und Elektroindustrie, Arbeitsamt Aachen. 
BIJLAGE B: VACATUREPROBLEMATIEK

OPENSTAANDE VACATURES

Vacatures naar beroepsgroep

Tabel I: Relatief aantal openstaande vacatures naar beroepsgroep (1990)

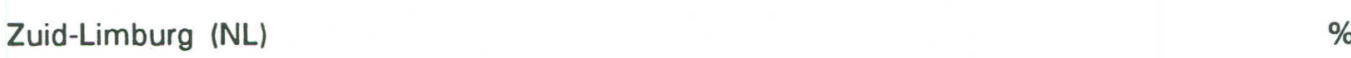

$\begin{array}{lr}\text { metaal } & 22 \\ \text { bouw B\&U } & 13 \\ \text { handel } & 11 \\ \text { personeel alg. dienst } & 10 \\ \text { horeca } & 9 \\ \text { kantoor } & 8\end{array}$

Bron: ETIL (1990) Openstaande vraag naar herstructureringsgebied.

Tabel II: Relatief aantal openstaande vacatures naar beroepsgroep (1991) ${ }^{1}$

Belgisch Limburg

$\%$

arbeiders:

metaalbewerker

27

werknemer verkeer

bouwarbeider

bedienden:

verkoper

17

andere bureaubedienden

technicus

15

Bron: VDAB (1991) Statistieken over de werkaanbiedingen uit het gewoon economisch circuit, in: Maandverslag Limburg.

1. Cijfer per december 1991. 
Tabel III Relatief aantal openstaande vacatures naar beroepsgroep (1992)

Org., Verwaltungs- u. Büroberufe ${ }^{2}$

Schlosser, Mechan. u. zug. Berufe ${ }^{3}$

15

Warenkaufleute

Reinigungsberufe

Bron: Statistik Arbeitsamt Aachen (25-03-1992).

\section{Vacatures naar opleidingsniveau}

Tabel IV De instroom van vacatures naar opleidingsniveau in het Gewest Maastricht (1991)

opleidingsniveau

ongeschoold

basis onvoltooid

LBO, MAVO

MBO, HAVO, VWO

$\mathrm{HBO}$

kandidaats/WO

instroom
abs. $\%$

29653

$6 \quad 1$

$133 \quad 24$

9016

275

20 vervullingsquote

$\%$

65

50

52

55

47

50

Bron: CBA (1991) LAVADA-bestand.

2. Organisations-, Verwaltungs-, und Büroberufe.

3. Schlosser, Mechaniker und zugehörige Berufe. 
$-58-$

Tabel V De instroom van vacatures en het relatieve aantal openstaande vacatures naar opleidingsniveau in Belgisch Limburg (1991)

\begin{tabular}{|c|c|c|c|c|}
\hline opleidingsniveau & \multicolumn{2}{|c|}{ instroom } & $\begin{array}{l}\text { vervullingsquote } \\
\qquad \%\end{array}$ & $\begin{array}{l}\text { openstaande } \\
\text { vacatures \% }\end{array}$ \\
\hline lager onderwijs & 4.415 & 43 & 78 & 27 \\
\hline lager sec.alg.vormend & 274 & 3 & 81 & 3 \\
\hline lager sec.technisch & 1.002 & 10 & 68 & 22 \\
\hline lager sec. beroeps & 735 & 7 & 77 & 10 \\
\hline hoger sec.alg.vormend & 214 & 2 & 79 & 3 \\
\hline hoger sec.technisch & 1.373 & 13 & 76 & 16 \\
\hline hoger sec.beroeps/aanv. & 545 & 5 & 74 & 5 \\
\hline hoger ond. 1 ste graad & 1.180 & 12 & 81 & 8 \\
\hline hoger ond.2de graad & 43 & 0 & 63 & 1 \\
\hline hoger ond.3de graad & 85 & 1 & 67 & 2 \\
\hline universitair & 206 & 2 & 71 & 2 \\
\hline middenstandsopl. & 140 & 1 & 66 & $\overline{0}$ \\
\hline andere & 20 & 0 & 85 & - \\
\hline
\end{tabular}

Bron: VDAB (1991) Statistieken over de werkaanbiedingen uit het gewoon economisch circuit, in: Maandverslag Limburg.

Tabel VI Het relatieve aantal openstaande vacatures naar opleidingsniveau in het Arbeitsamtbezirk Aachen (1991)

opleidingsniveau

openstaande

vacatures $\%$

ongeschoold 31

Ausbildung/Lehre 5

BFS/Fachschule

Hoch-/Fachh.schule

12

Bron: Statistiek Arbeitsamt Aachen (1992)

4. De gemiddelde vervullingsquote bedraagt $76 \%$; de weergegeven percentages zijn afgerond.

5. Te vergelijken met het Nederlandse leerlingwezen. 
MOEILIJK VERVULBARE VACATURES

Vacatures naar beroepsgroep

Tabel VII Aandeel moeilijk vervulbare vacatures naar beroepsgroep (1991)

\begin{tabular}{lclc}
\hline & $\begin{array}{c}\text { Westelijke } \\
\text { Mijnstreek } \\
\%\end{array}$ & $\begin{array}{c}\text { Oostelijke } \\
\text { Mijnstreek } \\
\%\end{array}$ \\
\hline Bouw B\&U & 33 & bouwnijv.en bouwinstall. & 29 \\
metaal & 24 & horeca & 12 \\
horeca & 11 & overige dienstverl & 12 \\
pers.alg.dienst & 10 & & \\
\hline
\end{tabular}

Bron: Gegevens RBA Zuid-Limburg

Tabel VIII Vacaturegegevens volgens de CBS vacature-enquête (1990)

Zuid-Limburg (NL)

Totaal aantal vacatures $(\times 1.000)$

Zoekperiode < 1 mnd.

Zoekperiode 1-3 mnd.

0.7

Gemeld bij arbeidsbureau

1.3

Moeilijk vervulbaar

Tabel IX Aandeel moeilijk vervulbare vacatures naar beroepsgroep (1991)

Belgisch Limburg \%

arbeiders:

metaalbewerker 32

electriciën $\quad 15$

$\begin{array}{ll}\text { bouwarbeider } & 12\end{array}$

bedienden:

verkoper 24

andere bureaubedienden $\quad 14$

technicus 10

Bron: VDAB (1991) statistieken over de werkaanbiedingen uit het gewoon economische circuit, in: Maandverslag Limburg. 
$-60-$

Tabel X Relatief lange vacatureduren naar beroep in het Gewest Aken (1991)

\begin{tabular}{lcc}
\hline soort beroep & $\begin{array}{c}\text { maanden } \\
\%\end{array}$ & $\begin{array}{c}\text { maanden } \\
\%\end{array}$ \\
\hline Arbeiter: & 66 & 71 \\
nicht Facharbeiter & 20 & 23 \\
Facharbeiter & 46 & 48 \\
Angestellte: & 51 & 29 \\
mit einfachen Tätigkeiten & 6 & 6 \\
mit gehobenen Tätigkeiten & 28 & 23 \\
& & 72 \\
qualifiziert & & 28 \\
nicht qualifiziert & 74 & 26 \\
\hline Bron: Statistik Arbeitsamt Aathe
\end{tabular}

Bron: Statistik Arbeitsamt Aachen (1992)

Vacatures naar opleidingsniveau

Tabel XI Gemiddelde vacatieduur en vervullingsquote naar opleidingsniveau voor het Gewest Maastricht ${ }^{7}$

\begin{tabular}{llc}
\hline opleidingsniveau & $\begin{array}{l}\text { vacatieduur } \\
\text { (dagen) }\end{array}$ & $\begin{array}{c}\text { vervullingsquote } \\
\%\end{array}$ \\
\hline ongeschoold & 24 & 65 \\
basis onvoltooid & 51 & 50 \\
LBO,MAVO & 41 & 52 \\
MBO, HAVO, VWO & 25 & 55 \\
HBO & 27 & 47 \\
Kandidaats/VWO & 30 & 50 \\
totaal & 28 & 58 \\
\hline
\end{tabular}

Bron: CBA (1991) LAVADA-bestand

6. Bestandcijfer per september 1991

7. De gegevens voor het Gewest Maastricht moeten weer als representatief voor geheel ZuidLimburg beschouwd worden. 
$-61-$

Tabel XII Relatieve aandeel moeilijk vervulbare vacatures en vervullingsquote naar opleidingsniveau in Belgisch Limburg (1991)

\begin{tabular}{lrc} 
opleidingsniveau & $\begin{array}{c}\text { 2 } \begin{array}{c}\text { mnd open } \\
\%\end{array} \\
\end{array}$ & $\begin{array}{c}\text { vervullingsquote } \\
\%\end{array}$ \\
\hline & 30 & 78 \\
lager onderwijs & 4 & 81 \\
lager sec.alg.vormend & 9 & 68 \\
lager sec.technisch & 16 & 77 \\
lager sec.beroeps & 2 & 79 \\
hoger sec.alg.vormend & 20 & 76 \\
hoger sec.technisch & 6 & 74 \\
hoger sec.beroepss/aanv. & 7 & 81 \\
hoger ond.1ste graad & 2 & 63 \\
hoger ond.2de graad & 1 & 67 \\
hoger ond.3de graad & 1 & 71 \\
universitair & 1 & 66 \\
middenstandsopl. & 1 &
\end{tabular}

Bron: VDAB (1991) Statistieken over de werkaanbiedingen uit het gewoon economisch circuit, in Maandverslag Limburg. 


\section{BIJLAGE C: WERKGELEGENHEID}

Tabel I Samenstelling van de werkgelegenheid (aantal banen) naar bedrijfssectoren (1988).

\begin{tabular}{lccc}
\hline & $\begin{array}{c}\text { Limburg (NL) } \\
\%\end{array}$ & $\begin{array}{c}\text { Belgisch Limburg } \\
\%\end{array}$ & $\begin{array}{c}\text { Gewest Aken } \\
\%\end{array}$ \\
& & & 1 \\
landbouw & 2 & 36 & 42 \\
nijverheid & 31 & 7 & 6 \\
bouwnijverheid & 7 & 11 & 17 \\
handel en horeca & 15 & 4 & 4 \\
verkeer en vervoer & 6 & 41 & 31 \\
overige diensten & 40 & &
\end{tabular}

Bron: CBS, LDS-NW, RSZ, ETIL (1990) Vraag en aanbod op de arbeidsmarkt in internationaal perspectief, p. 15. 


\section{BIJLAGE D: GRENSARBEID}

Tabel I Relatief aantal grensarbeiders woonachtig in Nederland, werkzaam in België (31-03-1991)

\begin{tabular}{lc}
\hline & \multicolumn{2}{c}{ werkzaam in België } \\
& $\%$ \\
\hline & \multicolumn{2}{c}{6} \\
Zuid-Holland & 24 \\
Zeeuws-Vlaanderen & 4 \\
overig Zeeland & 33 \\
West Noord-Brabant & 3 \\
Midden Noord-Brabant & 10 \\
Zuidoost Noord-Brabant & 4 \\
Midden-Limburg & 16 \\
Zuid-Limburg & 16 \\
\hline
\end{tabular}

Bron: CBS Statistiek Grensarbeid

Tabel II Relatief aantal grensarbeiders woonachtig in België, werkzaam in Nederland (31-03-1991)

werkzaam in: woonachtig in België

$\%$

$\begin{array}{lr}\text { Zuid-Holland } & 1 \\ \text { Zeeuws-Vlaanderen } & 10 \\ \text { overig Zeeland } & +0 \\ \text { West Noord-Brabant } & 9 \\ \text { Midden Noord-Brabant } & 3 \\ \text { Zuidoost Noord-Brabant } & 28 \\ \text { Midden-Limburg } & 9 \\ \text { Zuid-Limburg } & 33\end{array}$

Bron: CBS Statistiek Grensarbeid

Tabel III Relatief aantal grensarbeiders woonachtig in Nederland, werkzaam in BRD (31-03-1991)

woonachtig in:

werkzaam in België

$\%$

$\begin{array}{lr}\text { Zuid-Holland } & 1 \\ \text { Zeeuws-Vlaanderen } & 1 \\ \text { overig Zeeland } & 8 \\ \text { West Noord-Brabant } & 16 \\ \text { Midden Noord-Brabant } & +0 \\ \text { Zuidoost Noord-Brabant } & 3 \\ \text { Noord-Limburg } & 16 \\ \text { Midden-Limburg } & 9 \\ \text { Zuid-Limburg } & 45\end{array}$

Bron: CBS Statistiek Grensarbeid 
$-64-$

Tabel IV Relatief aantal grensarbeiders woonachtig in de BRD, woonachtig in Nederland (31-03-1991)

werkzaam in:

woonachtig in België

$\%$

Overijssel

20

Gelderland

16

Zuid-Holland

4

Noord-Brabant

10

Noord-Limburg

9

Midden-Limburg

26

Zuid-Limburg

Bron: CBS Statistiek Grensarbeid 